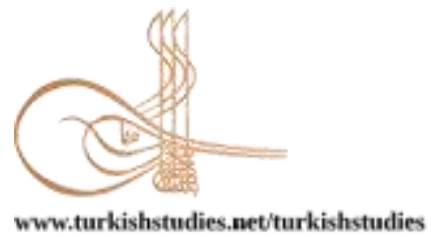

Turkish Studies

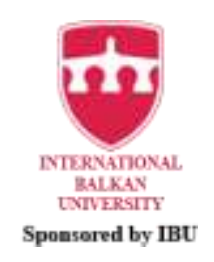

\title{
Beyaz Zeminli Uşak Halılarından Bilinmeyen Bir Grup: Akrep Motifli Selendi Halıları
}

\author{
An Unknown Group from White Ground Uschak Rugs: Selendi Rugs with Scorpion Motif
}

\author{
Servet Senem Uğurlu*
}

\begin{abstract}
In the beginning of the 20th century, in the Transylvanian churches in the Balkan Peninsula, the 16th-17th dated to the centuries, nearly 400 carpets belonging to the early and classical periods of the Ottoman Carpet Weaving, have been identified. These carpets generally attract attention with the size of prayer rugs and their pattern composition. There are many different groups among the Ottoman rugs found in Transylvania. Among these, Uschak Rugs with White Grounds are quite a different group. It is thought that these carpets were woven in the province of Uşak in the past, and in the town of Selendi, which is connected to the province of Manisa today. The pattern compositions of Uschak carpets with a white background are named as bird, Chintamani, triple points and scorpion. In Ottoman documents and records, such as the Es'ar Book of 1640, other carpets are mentioned, apart from carpets with scorpion motifs. World-renowned carpet experts such as Kurt Erdmann, Ferenc Batári, Marino Dall'Oglio, Stefano Ionescu, Michael Franses admit that although there is no record of the Scorpion motif carpets, these carpets were woven in the same workshop as other carpets in Selendi. World-renowned carpet experts argue that the scorpion-patterned carpets and other white-based Selendi carpets have the same material, technique, application properties and colour similarities. Foreign researchers have defined the scorpion motif as the scorpion, the crab, the struggle of two geometrically stylized animals. The scorpion motif was developed in a square unit, and it was placed between the motifs forming columns in the area in the middle of the carpet in full and staggering repeats. Straight, interrupted and diagonal lines were used in the creation of the motifs. The aim of choosing the subject of "An Unknown Group of White-Ground Uschak Rugs: Selendi Carpets with Scorpion Motifs" as a research; the fact that it has not been noticed before in research and publications on Turkish Carpet Weaving in our country. The absence of a sample of this carpet group in Turkey is a deficiency for Turkish Carpet Weaving. There are four different examples in museums and collections abroad. In addition, there are international publications that are considered to be pioneers in this field. In this study, the motif and pattern feature of Selendi Rugs with Scorpion Motifs, which are among the White Ground Uschak Rugs, which are among the Ottoman Uschak Rugs, which are unknown and unrecognized in our country, will be examined. The reasons for these carpets to be found in Transylvanian churches and the geographical and social structure of the region will be investigated.
\end{abstract}

Structured Abstract: Although a lot of research has been done on Turkish rugs, there will be much more information and findings to be researched. In 1957, Kurt Erdmann stated that the scientific study of Eastern carpets, which emphasized Anatolia in particular, started in the last quarter of the 19th century, and then

*Dr. Öğr. Üyesi, Mimar Sinan Güzel Sanatlar Üniversitesi, Güzel Sanatlar Fakültesi, Geleneksel Türk Sanatlar1 Bölümü Asst. Prof. Dr., Mimar Sinan Fine Arts University, Faculty of Fine Arts, Department of Traditional Turkish Arts ORCID 0000-0003-2307-9623

senem-ugurlu@windowslive.com

Cite as/ Atıf: Uğurlu, S. S. (2021). Beyaz Zeminli Uşak halılarından bilinmeyen bir grup: Akrep Motifli Selendi hal1lar1. Turkish Studies, 16(4), 1311-1333. https://dx.doi.org/10.7827/TurkishStudies.51514

Received/Geliş: 25 May/Mayıs 2021

Accepted/Kabul: 25 August/Ağustos 2021

Checked by plagiarism software

Published/Yayın: 30 August/Ağustos 2021

CC BY-NC 4.0 
continued with the material collection-sorting-processing periods, and as a result, a rich literature was formed.

\section{Introduction and Purpose}

"These studies have progressed so much in some fields today that we are now able to see the development of carpets in general terms. However, some issues remain unanswered. Especially there are many things we do not know about Turkish carpets" (Erdmann, undated: 83).

It is inevitable that the information in the field of Turkish Carpet Weaving should be updated by combining the old researches made in the Turkish Carpet Weaving literature with new researches. "New findings and new observations can change the picture over and over again. This is the fascinating thing that we think we know very well about the oriental rug and basically still know very little about it" (Erdmann, 1966: 11). In his researches on Eastern Carpets and Turkish Carpets, Kurt Erdmann pointed out that Turkish Carpet Weaving should be updated with new information and old examples that can be accessed day by day.

Detailed information in foreign publications in English and German about "White Ground Selendi Carpets with Scorpion Motif" within the white ground Uschak Rug Group is given. There are no examples of Selendi carpets with scorpion motifs that foreigners realized in 1933, but only four examples have survived to the present day all over the world. This interesting group, which is known by carpet researchers in the world, needs to be brought to the Turkish carpet literature in detail.

White Ground Selendi Rugs with Scorpion Motif is a group of carpets that are ignored in Turkish publications, probably because few people unknown. This carpet group should be included in the White Ground Uschak Rugs within the group of 16th-17th centuries Ottoman Uschak Carpets.

The aim of the research; white ground Selendi rugs scorpion motif is introduced to with their interesting aspects and in detail, the researchers in the field of Turkish Carpets in Turkey, examined by giving information about the carpets and added to Turkish Carpets as a group. In the research, the material, technique, colour, motif and pattern features of Selendi rugs with scorpion motif will be given information and this carpet group will be researched and its importance will be emphasized.

\section{Scope of Research}

Scope of research; includes white ground Selendi rugs with scorpion motif. The white ground Selendi rug group with scorpion motif has no examples in museums and private collections in Turkey. All over the world, there are four carpet samples in total in local museums, churches and private collections. Since there is no sample of white ground Selendi rugs with scorpion motif in our country and there are no Turkish publications explaining the subject in a comprehensive way, it is planned to update and increase the literature information with new information obtained about Turkish rug weaving.

\section{Conceptual Framework}

White ground Selendi rugs with scorpion motif within the white ground Uschak rugs group are examples of carpets that the Western world became aware of in 1933. From the documents and records of the collections containing rugs, it was understood that they were woven in Selendi district of Uschak and its surroundings. There are a total of four publications, two of which are published and two of which are unpublished, prepared in Turkish which are considered to be pioneers in this field.

\section{Method}

In the research, primarily foreign sources were taken as the center. Afterwards, the printed sources in Turkey and the theses in the digital archives of the Council of Higher Education Thesis Center and Turkish university libraries were scanned and the information on the subject was written. His books "Antique Ottoman Rugs in Transylvania", published in Rome by the Romanian Cultural Institute in 2005 and 2007, written by Stefano Ionescu, who conducts research on Transylvanian Carpets, are publications in foreign languages that provide comprehensive information on the topic. White ground Selendi rugs with scorpion motif, which are well known by Western carpet researchers in the world, should be brought into Turkish Carpets. 


\section{Results and Discussion}

With this research, the similarities of white ground Selendi rugs with scorpion motif and white ground Selendi rugs with have been determined. In the research, only four carpet samples, which have survived to the present day and are preserved in museums, churches and private collections abroad, were examined. The motifs of the carpet centres and borders in the examples and the pattern compositions have been extracted. It has been observed that the colour of the borders and middle ground of carpets with scorpion motifs is always white. Due to the interest shown in Western Anatolian carpets in Transylvanian churches in the 20th century, many imitations of these carpets, as seen in many works of art; It was weaved by Romanian Theodor Tuduc, a master carpet repairer and carpet manufacturer, in his workshop near Braşov between 1930-1960. Tuduc's fake carpets, indistinguishable from their originals, have been sold to many important museums and collections around the world. Tuduc completed some of the old carpet parts with the carpet repair he made, and the new parts were worn out in a way that experts could not notice. Tuduc fooled museums, collectors, and auction houses, as these rugs look quite realistic and old. These rugs were Tuduc, who misused the admiration of Western Anatolian carpets, was a carpet fraud of the century. These fake replica carpets have also proved the artistic value of Anatolian carpets as well as being commercial goods.

\section{Conclusions and Recommendations}

It is known that there are approximately four hundred Anatolian rugs that are preserved in whole or in pieces, dating from the second half of the 15th century to the end of the 18th century, in the church and museum warehouses of the Saxon and Hungarian Protestant community in the Transylvania region. Yörük and Turkmens who came with Sarı Saltuk, one of the colonizer Turkish dervishes, settled in this region.

After the Mohac War in 1526, it caused an increase in carpet trade in the Transylvania region. Carpet merchants from many European countries brought the Western Anatolian carpets sold in Istanbul to Transylvania, especially in the direction of the Danube River. This route is one of the most affordable and cost-effective transportation options for Central Europe. Carpet trade in the Transylvania region continued until the end of the 18th century. These carpets in Transylvania attracted the attention of foreign carpet sellers in the second half of the 19th century. With the idea of buying cheap and selling high in Northern European countries, a process called "Carpet Hunt Period" started. Hundreds of carpets have been sold in as little as 25 years. The carpets in the area were stolen or sold for nothing. Saxons living in this region preserved their Anatolian carpets as a cultural treasure and donated their carpets to churches. A large number of carpets have survived in Transylvania, thanks to Saxon families in Romania donating their carpets to the church and helping to maintain the carpets in churches. When the Turkish carpet types in this region are examined, they are the size of prayers that are easy to carry. Interest in Western Anatolian carpets in Transylvanian churches gradually increased in the 20th century.

Emil Schmutzler (1889-1952), a member of a family with a textile company in Romania, created a collection of 15-20 carpets bought from Saxon families in the rural areas in his two mansions built in the countryside. In 1933 he published his book "Altorientalische Teppiche in Siebenbürgen" in Leipzig. His book was printed in color with the latest technology and it gave him prestige because it was the first book about Transylvanian carpets. Eight carpets were recovered from his home collection, which was bombed during World War II in 1944 (Ionescu, 2005: 209-210).

Between 1930 and 1960, Romanian master carpet mechanic and carpet manufacturer Theodor Tuduc had copies of rugs in Transylvanian churches weaved in his workshop. Rug experts in museums, collectors and auction houses could not understand that Tuduc's fake rugs were fake. The fake rugs of Tuduc, the rugs fake of the century, are found in many museums and collections around the world today. This fraud has been important evidence of the artistic value of Anatolian rugs.

It is known from Ottoman records that the white ground carpet group among the Ottoman Uschak Rugs was woven in the Selendi district of Manisa. These carpets are referred to as Chintamani, three points, with bird / crow until today. However, a special group in Transylvania, dating to the 17 th century and associated with the white ground Selendi rugs; it is known by experts and researchers who research Anatolian rugs.

Of the carpets named as Selendi rugs with scorpion motif, only four of them reached the present day. Some researchers and experts have called the scorpion motif as crab, sometimes vegetative leaf and 
broken branch. It is even claimed that two animals are fighting. These claims will continue. Because iconographic motifs, which have different meanings than they appear in traditional weavings, are open to various interpretations.

As a result; in this study, white ground Selendi carpets with scorpion motif, which were almost never mentioned in Turkey in Turkish Carpets and were not classified in carpet groups, were examined. The motif and pattern compositions of these carpets have been extracted and their design features have been explained. The Selendi carpet group with scorpion motifs on a white background has been tried to be included in the Turkish Rugs literature in Turkey.

Keywords: Carpet-kilim and old fabric design, Transylvania, scorpion, Selendi, Uschak, rug

Öz: 20. yüzyıl başında Balkan Yarımadasında Transilvanya kiliselerinde 16.-17. yüzyıllara tarihlendirilen Osmanlı Halıcılığının erken ve klasik dönemine ait 400'e yakın halı tespit edilmiştir. Bu halılar genellikle namazlık boyutlarında ve desen kompozisyonlarında olmaları ile dikkat çekmektedir. Transilvanya'da bulunan Osmanlı halıları içerisinde birbirinden çok farklı gruplar vardır. Bunlar içerisinde Beyaz Zeminli Uşak Halıları oldukça farklı bir gruptur. Bu halılar, geçmişte Uşak iline, günümüzde ise Manisa iline bağlı olan Selendi ilçesinde dokunduğu düşünülmektedir. Beyaz zeminli Uşak halılarının desen kompozisyonları kuşlu, çintemanili, üç benekli ve akrepli olarak isimlendirilmektedir. 1640 tarihli Es'ar Defteri gibi Osmanlı belge ve kayıtlarında Akrep motifli halılar dışında diğer halıların adı geçmektedir. Kurt Erdmann, Ferenc Batári, Marino Dall'Oglio, Stefano Ionescu, Michael Franses gibi dünya çapında önemli halı uzmanları, Akrep motifli halıların hakkında kayıt bulunmamasına karşın bu halıların Selendi'de diğer halılarla aynı atölyede dokunduğunu kabul etmektedirler. Bu uzmanlar neden olarak akrep motifli halılar ile diğer beyaz zeminli Selendi halılarının aynı malzeme, teknik, uygulama özellikleri ve renk benzerliklerinin olduğunu belirtmektedirler. Dünya çapında önemli halı uzmanları, akrep motifini akrep, yengeç, geometrik olarak stilize edilmiş iki hayvanın mücadelesi olarak tanımlamışlardır. Akrep motifi kare birim içerisinde geliştirilmiş, halı ortasındaki alanda sütun oluşturan motifler arasına tam ve şaşırtmacalı raportlar halinde yerleştirilmiştir. Motiflerin oluşturulmasında düz, kırık ve diyagonal çizgiler kullanılmıştır. Araştırma olarak "Beyaz Zeminli Uşak Halılarından Bilinmeyen Bir Grup: Akrep Motifli Selendi Halıları" konusunun seçilmesindeki amaç; ülkemizdeki Türk Halıcılığı ile ilgili araştırma ve yayınlarda daha önceden fark edilmemiş olmasıdır. Bu halı grubunun Türkiye'de günümüze ulaşan örneğinin olmaması, Türk Halıcılığı için eksikliktir. Yurtdışı müze ve koleksiyonlarda dört farklı örneği bulunmaktadır. Ayrıca bu konuda öncü olarak kabul edilen yurtdışı yayınlar vardır. Bu araştırmada, ülkemizde bilinmeyen ve tanınmayan Osmanlı Uşak Halıları içerisindeki Beyaz Zeminli Uşak Halılarından Akrep Motifli Selendi Halılarının, motif ve desen özellikleri incelenecektir. Bu halıların Transilvanya kiliselerinde bulunma nedenleri, bölgenin coğrafi ve sosyal yapısı araştırılacaktır.

Anahtar Kelimeler: Hal1-kilim ve eski kumaş desenleri, Transilvanya, akrep, Selendi, Uşak, halı

\section{Giriş}

Türk halıları hakkında çok araştırma yapılmış olmasına karşın daha araştıılacak çok sayıda bilgi ve bulgu olacaktır. 1957 y1lında Kurt Erdmann özellikle Anadolu’yu vurgulayan Doğu halılarının bilimsel olarak incelenmesine 19. yüzyılın son çeyreğinde başlandığını, sonrasının ise malzeme toplama-toplanan malzemeyi tasnif etme-işleme dönemleriyle devam ettiğini ve sonuç olarak zengin bir literatür oluştuğunu belirtmiştir: "Bu çalışmalar bugün bazı sahalarda öylesine ilerledi ki artık halıların gelişmesini ana hatlarıyla görebilecek haldeyiz. Ama yine de bazı meseleler cevapsız kalmış bulunuyor. Bilhassa Türk halıları bahsinde bilmediğimiz pek çok şeyler vardır" (Erdmann, tarihsiz: 83).

Türk Halıcılığı literatüründe yapılan eski araştırmaların yeni araştırmalarla birleştirilerek Türk Halıcılığı alanında bilgilerin güncellenmesi gerektiği kaçınılmazdır. "Yeni bulgular ve yeni gözlemler, resmi tekrar tekrar değiştirebilir. Oryantal halıyı çok iyi bildiğimizi ve temelde hala onun hakkında çok az şey bildiğimizi düşündügümüz büyüleyici şey bu” (Erdmann, 1966: 11). 
Doğu Halıları ve Türk Halıcılığı hakkında yaptığı araştırmalarda Kurt Erdmann, Türk Halıcılığının her geçen gün ulaşılabilen eski örnekler ve bunların yeni bilgilerle güncellenmesi gerektiğine işaret etmiştir. Bu konuda Anadolu'nun kültürel zenginliği hakkında halk deyişleri de bulunmaktadır: Kuzeybatı Anadolu'da "Zengindin hani partalların, şişmandın hani sarkanların” ve "Anadolu un çuvalına benzer, salladıkça tozar" gibi özlü söz örnekleri ile çok sayıda bilindiğinden ve görünenden farklı anlamlar taşıyan şeyin araştırılması gerektiğine işaret edilmektedir.

\section{Araştırmanın Amacı}

Beyaz zeminli Uşak halı grubu içerisindeki “Akrep Motifli Selendi Halıları" hakkında İngilizce ve Almanca hazırlanmış yurtdışı yayınlarda detaylı bilgiler verilmektedir. Yabancıların 1933 yılında farkına vararak tespit ettiği akrep motifli Selendi halılarından örnekler ülkemizde yoktur, ayrıca tüm dünyada sadece dört örnek günümüze ulaşabilmiştir. Dünyadaki halı araştırmacıları tarafindan tanınan bu ilginç grubun, Türk halıcılığı literatürüne ayrıntılı biçimde kazandırılmas1 gerekmektedir.

Büyük ihtimalle az kişi tarafindan bilindiği için, Türkçe yayınlarda yazılması göz ardı edilen bu halı grubu, Türk Halıcılığında 16.-17. yüzyıllardaki Osmanlı Uşak Halıları grubu içerisine dahil edilmemiş, Beyaz Zeminli Uşak Halılarından bilinmeyen bir grup olan Akrep Motifli Selendi Halıları'nın ülkemizdeki halı meraklılarına ilginç yönleriyle ayrıntılı olarak tanıtılması, bu halılar hakkında bilgi verilerek incelenmesi ve Akrep Motifli Selendi Halılarının Türk Halıcılığına grup olarak eklenmesi; araştırmanın amacıdır. Araştırmada akrep motifli Selendi halılarının malzeme, teknik, renk, motif ve desen özellikleri hakkında bilgiler verilerek bu halı grubunun araştırılması yapılacak ve önemi vurgulanacaktır.

\section{Araştırmanın Kapsamı}

Araştırma kapsamı; beyaz zeminli akrep motifli Uşak Selendi halılarını içermektedir. Beyaz zeminli akrep motifli Selendi halı grubunun Türkiye'deki müze ve özel koleksiyonlarda örneği yoktur. Tüm dünyada ise müze, kilise arşivi ve özel koleksiyonlarda olmak üzere toplam olarak dört halı örneği bulunmaktadır. Beyaz zeminli akrep motifli Selendi halısı örneğinin ülkemizde olmaması ve konuyu kapsamlı olarak açıklayan yaygın Türkçe yayın bulunamaması nedeniyle, ülkemizdeki Türk Halıcılığı hakkında elde edilen yeni bilgilerle literatür bilgilerinin güncellenerek arttırılması düşünülmektedir.

\section{Kavramsal Çerçeve}

Beyaz zeminli Uşak halı grubu içersindeki “Akrep Motifli Selendi Halıları”, Batı dünyasının 1933 yılında farkına vardığı halı örnekleridir. Halıların bulunduğu koleksiyonların evrak ve kayıtlarından önceleri Uşak iline, sonrasında ise Manisa iline bağlı Selendi ilçesi'nde ve çevresinde dokunmuş olduğu anlaşılmıştır.

Akrep motifli Selendi halıları, Anadolu'da dokunmuş olmasına karşın ülkemizde örneği bulunmadığı için genellikle Türk araştırmacılar tarafından pek bilinmemekte ve bu halı grubundan bahsedilmemektedir. Tüm dünyada akrep motifli Selendi halılarından günümüze toplam dört örnek ulaşabilmiştir. Dünyada Batılı halı araştırmacıları tarafından oldukça iyi tanınan bu grubun Türk Halıcılığı tarihçesine kazandırılması gerekmektedir.

Araştırmada öncelikle yabancı kaynaklar merkez olarak alınmış, daha sonrasında ise Türkiye'deki basılı kaynaklar ve Yükseköğretim Tez Merkezi ile Türk üniversite kütüphanelerinin dijital arşivlerindeki tezler taranmış, konuyla ilgili bilgilerin dökümü yapılmıştır. Bu konuda öncü kabul edilen Türkçe olarak hazırlanmış iki adet basılmış ve iki adet basılmamış olmak üzere toplam dört adet yayın olduğu görülmüştür.

Transilvanya Halıları hakkında araştırma yapan Stefano Ionescu'nun yazdığı Roma'da basılan, Romanya Kültür Enstitüsü tarafından 2005 ve 2007 yıllarında yayımlanan "Antique 
Ottoman Rugs in Transylvania" adlı kitapları, konu hakkında kapsamlı bilgiler veren yabancı dilde basılmış bir yayındır.

“Akrep Motifli Selendi Halıları”nın Türk Halı literatürüne halı grubu olarak eklenmesi, malzeme, teknik, renk, motif ve desen özellikleri hakkında bilgiler verilmesi, halı grubunun Türk halıcığındaki önemi vurgulanması kavramsal çerçevede vurgulanacak bilgilerdir.

\section{Bulgular ve Tartışma}

$\mathrm{Bu}$ araştırma ile beyaz zeminli akrep motifli Selendi halılarının yine aynı özellikteki beyaz zeminli Selendi halıları ile benzerlikleri tespit edilmiştir. Araştırmada günümüze ulaşan ve yurtdışındaki müze, kilise ve özel koleksiyonlarda korunan, dünyada sadece dört adet bulunan halı örnekleri incelenmiştir.

Örneklerdeki halı ortaları ve bordürlerinin motifleri ile desen kompozisyonları çıkartılmıştır. Akrep motifli halıların bordürleri ile orta zemin renginin daima beyaz olduğu görülmüştür.

20. yüzyılda Transilvanya kiliselerindeki Batı Anadolu halılarına gösterilen ilgi nedeniyle, bir çok sanat eserinde görüldüğü gibi bu halıların çok sayıda taklidi; usta halı tamircisi ve halı üreticisi olan Romanyalı Theodor Tuduc tarafından Braşov yakınındaki atölyesinde 1930-1960 yılları arasında dokutturulmuştur. Orijinallerinden ayırt edilemeyecek biçimde olan Tuduc'un sahte halıları, dünyadaki çok sayıda önemli müze ve koleksiyonerlere satılmıştır. Tuduc bazı eski halı parçalarına yaptığı halı tamiri ile halıyı tamamlayarak bütünlemiş, yeni bölümleri ise uzmanların farkedemeyeceği biçimde eskitmiş̧ir (Ionescu, 2005: 212-215). Bu halılar oldukça gerçekçi ve eski göründüğü için, Tuduc müze, koleksiyoner ve müzayede evlerini kandırmış, Batı Anadolu halılarının beğenisini kötü amaçla kullanan Tuduc, yüzyılın halı sahtekarlığını yapmıştır. Bu sahte kopya halılar, aynı zamanda Anadolu halılarının ticari mal olmasının yanı sıra sanatsal değerinin kanıtı olmuştur.

\section{Türkçe Kaynaklarda Bahsedilen Bilgiler}

Ülkemizde Türkçe basılı kitap ve lisansüstü tezler incelendiğinde; biri Türkiye'de diğeri Macaristan'da Türkçe olarak basılmış iki kitapta ve iki yüksek lisans tezinde beyaz zeminli Akrep motifli Selendi halıları hakkında bilgiler verilmektedir. Ancak tüm bu yayınlarda bu grubun tüm örnekleri ve özellikleri bir araya getirilmemiş, genel ve kısa bilgiler verilmiştir.

Türkçe araştırmalarda beyaz zeminli akrep motifli Selendi halılarından ilk bahseden Michael Franses olmuştur. "Tanrı'ya Adanmış Halılar Transilvanya Kiliselerinde Anadolu Halıları 1500-1750" başlıklı kitapta "Transilvanya Kiliselerinde Osmanlı Halıları" isimli kitap bölümünde günümüzde akrepli ya da yengeçli ismiyle tanınan yalnızca dört halı olduğunu yazmıştır (Ionescu, 2007: 69).

İlk halının Braşov'daki Kara Kilise'de; ikinci halının daha önce Richiş Evangelist Kilisesi'nde olan diğer halının ise bugün Mediaş'taki St. Margaret Kilisesi'nde; üçüncü halının Budapeşte Uygulamalı El Sanatları Müzesi'nde, dördüncü halının ise İngiltere'deki Keir Koleksiyonu'nda olduğunu belirtmiştir. Macaristan ve İngiltere'deki halıların ise kesinlikle Transilvanya kiliselerinden geldiğini vurgulamıştır.

$\mathrm{Bu}$ halılar hakkında ayrıca "Akrepli dört halıdan üçünde akrep benzeri süslerden (büyük olasılıkla mücadele eden iki yaratık motifinin bir biçimi) oluşan iki dikey sütun vardır; Keir halısında "akrepli" üç sütun ve tırtıklı motifin yer aldığı bordür görülür" (Franses, 2007: 69) diye belirtmiştir.

Ayrıca Mediaş St. Margaret Kilisesinde bulunan akrep motifli halının fotoğrafını, Resim 28'de yazıya eklenmiştir (Franses, 2007: 68). Bu önemli sergi, Transilvanya Luteryan-Protestan 
Kiliselerindeki Batı Anadolu Halıları, günümüz ilgili ve meraklılarına tanıtılmış ve konunun tabana yayılmasında ivme getirmiştir.

Türkçe araștırmalarda beyaz zeminli akrep motifli Selendi halılarından ikinci olarak bahseden Emese Pásztor'dur. Budapeşte Uygulamalı Sanatlar Müzesi Koleksiyonundan Osmanl1Türk Halıları Ferenc Batari Anısına" adlı Türkçe'ye çevrilmiş kitabın katalog bölümünde 22. sırada ve Budapeşte Uygulamalı Sanatlar Müzesinde 7968 envanter numaralı akrep motifli halı görseli ve halı hakkında katalog bilgileri vardır (Pásztor, 2007: 106-107). Ayrıca Budapeşte Mediaş kentindeki St. Margaret Kilisesinde bulunan akrep motifli halının fotoğrafı, Resim 28 'de yazıya eklenmiştir (Pásztor, 2007: 107).

Türkçe araştırmalarda beyaz zeminli akrep motifli Selendi halılarından üçüncü olarak bahseden araştırmacı Berna İleri’dir. Berna İleri, yüksek lisans tezinde Michael Franses’i kaynak göstermiş ve sergi kataloğunda yazdığı kitap bölümünden özetleyerek aktarmıştır. "Beyaz zeminli halılar grubunun en az rastlanan örneklerinden biri Akrepli Halı olarak adlandırılan gruptur. Halının zemini dikey olarak rozet çiçek ve bu çiçeklerden çıkan geometrik şekillerle iki dikdörtgen alana bölünmüştür" (İleri, 2010: 56).

Ayrıca halıların hangi koleksiyonlarda olduğunu yazmıştır. "Günümüzde bu halıların bilinen dört örneği bulunmaktadır. Bunlardan biri Budapeşte Uygulamalı Sanatlar Müzesi, ikisi Transilvanya' da kilise koleksiyonlarında, biri de Londra'da Keir Koleksiyonu'nda bulunmaktadır" (İleri, 2010: 56-57). Tez metnine Budapeşte'deki Mediaş St. Margaret Kilisesinde bulunan Akrepli halının fotoğrafını, 28 numaralı resim olarak eklemiştir (Pásztor, 2007; 106-107; İleri, 2010: 57).

Türkçe araştırmalarda dördüncü olarak bahseden, beyaz zeminli akrep motifli Selendi halılarının görsellerini ayrıntı olarak veren (Boz, 2013: 134-135) ve bu halılarından iki tanesini kapsamlı olarak açıklayan Levent Boz'dur. "Transilvanya Bölgesi Lutherci Azize Mediaş Kilisesindeki Anadolu Halıları" başlıklı yüksek lisans tezinde Romanya'nın Mediaş şehrindeki St. Margaret Kilisesi Koleksiyonunda bulunan iki akrepli halıyı bulunduğu yerde incelemiş ve St. Margaret Kilisesinde korunan beyaz zemin akrep motifli Selendi halıları hakkında tezin katalog bölümünde 16. örnek olarak ayrıntılı biçimde açıklanmıştır (Boz, 2013: 124, 134, 135, 136, 205, 206).

$\mathrm{Bu}$ araştırma incelenen konunun 1933 yılından beri yabancı araştırmacılar tarafindan araştırıldığı ve uluslararası yayınlarda bilindiği görülmüş ve Beyaz Zeminli Akrep Motifli Selendi Halıları başlığında yapılan bir araştırma ile Türk Halıcılığına dahil edilerek tanıtılması hedeflenmiştir.

\section{Coğrafi Konum ve Sosyal Durum}

Transilvanya; Balkan Yarımadasında, Tuna'nın kuzeyindeki bölgede Romanya ve Macaristan sınırını oluşturan Karpat dağlarındaki yayladır. Bölgenin tarihsel süreç içerisinde farklı ülkelerde farklı isimlerle adlandırıldığ 1 bilinmektedir. Osmanlı İmparatorluğu döneminde genellikle Eflak-Boğdan-Moldova gibi isimlerle anılmıştır. Transilvanya, Saksonların yaşadığı özerk bir bölge olduğundan Almanca "Siebenbürgen", Macarca "Erdel" olarak bilinir (Ionescu, 2005: 19). Bölgeye bir çok kez giden Evliya Çelebi'nin Seyahatnamesinde ise "Erdel" ya da "Erdelistan" olarak geçmektedir (Kahraman, 2013: 7/180, 7/187).

Transilvanya, Osmanlı yönetiminde bazen isyan, bazen özerk voyvodalık, dost, ticari ve transit bölgesi olmuştur. Tarihsel süreç içerisinde Transilvanya; Hun, Avar, İskit/Saka ve Macar, Bulgar, Leh/Polonya, Ulah/Makedon, Alman, Kıpçak/Peçenek, Hazar, Oğuz/Uzlar, Romen, İtalyan, Doğu Romalı, Rus, Tatar ve Anadolu Selçukluları gibi çeşitli grupların ve inanç çeşitliliğinde toplumların yaşadığı bölge olmuştur. Bu bölge, Anadolu Yarımadasının Batı yönünde olan denizyolu bağlantısının karayolu alternatifidir. 
I. Dünya Savaşı sonunda bölge Romanya'da kalmıştır. Transilvanya, ayrıca Orta ve Doğu Avrupa ile Kuzey ve Güney Avrupa ülkelerinin karayolu bağlantısında bulunmaktadır. Bu bölge, çeşitli ırkların buluştuğu, isyan, soygun ve ticareti ile hareketli ilginç bir coğrafyadır (Ionescu, 2005: 24). Transilvanya'nın haftalık pazarları ve mevsimlik panayırları daima dikkat çeken çeşitlikte olmuştur. Evliya Çelebi'nin Erdel bölgesi anlatımlarında; Varot, Ösek, Dolyan, Alasonya, Maşkolor, Foşhan, Çöplüce panayırlarından bahsetmesi, bölgede ticari hayatın hareketliliğini kanitlar (Kahraman, 2013: 184).

Orijinalleri Romanya Sibiu kentindeki Brukenthal Museum'da bulunan, yaklaşık olarak 1800'lerde ressam Franz Neuhauser (1763-1836) tarafindan suluboya olarak kopyalanan “Transilvanya'da Panayır" resmi (Ionescu, 2007: 26-27); daha sonra ressam Josef Lanzedelli (1772-1831) tarafından da litografi bask1 resim serisi olarak yapılmıştır (URL1).

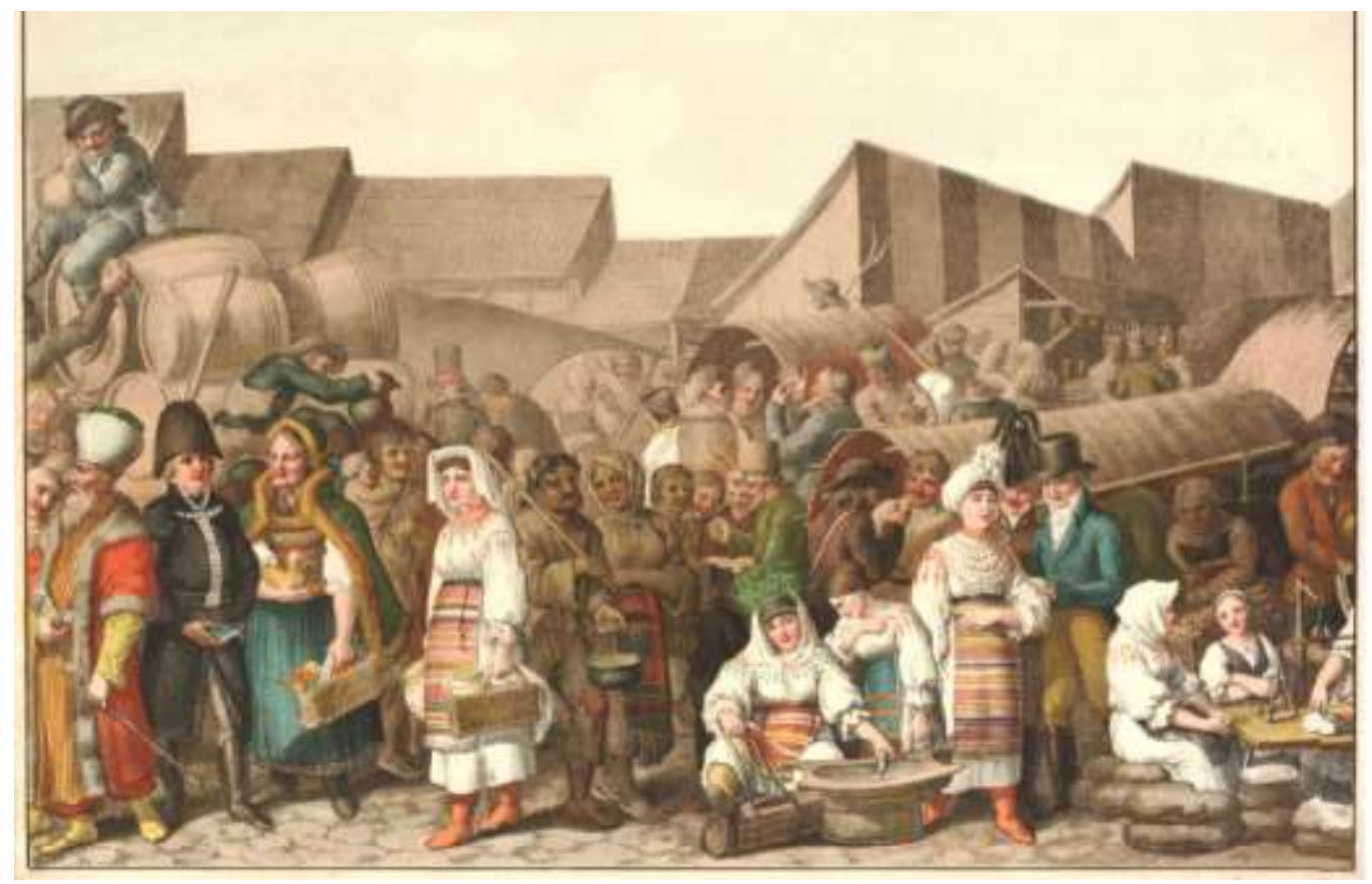

Resim 1. Transilvanya'da Y1llık Panayır (1819), Josef Lanzedelli (1774-1832), 353x528 mm, British Museum, Envanter Numaras1 1894,0612,75, (URL2)

Resim 2 de kumaş satıcısı, Resim 3 ve Resim 4'te ise Osmanlı kıyafetleri giyinmiş insanlar vardır. Resim 4 'te ayrıca bir kebe satıcısı görülmektedir. Altı parçadan oluşan serinin üç parçasına ulaşılmış, resimler birleştirilerek Transilvanya panayırları hakkında panoramik görüntü sağlanmıştır. 


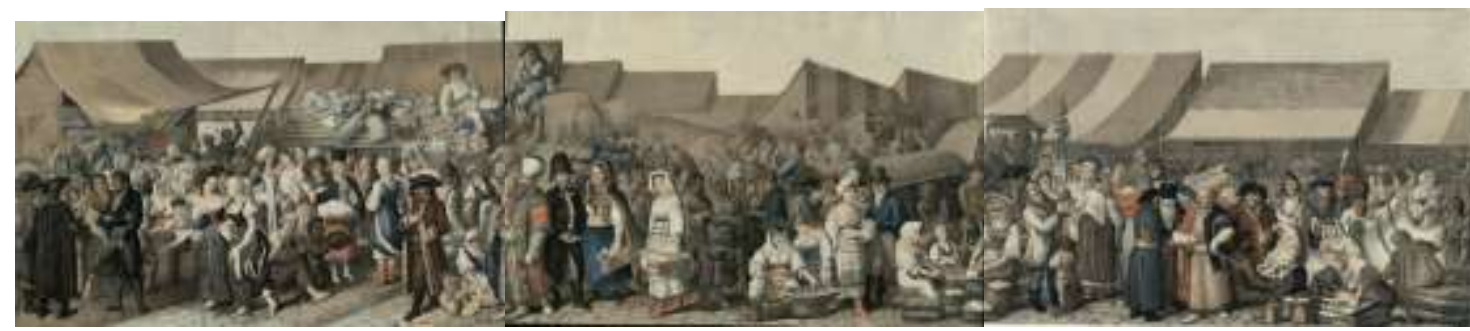

Resim 2. Transilvanya'da Panayır, Josef Lanzedelli, renkli litografi, 1818, Macaristan Akademisi Kütüphanesi (URL3)
Resim 3. Transilvanya'da Panayır, Josef Lanzedelli, renkli litografi, 1818, Macaristan Akademisi Kütüphanesi (URL4)
Resim 4. Transilvanya'da Panayır, Josef Lanzedelli, renkli litografi, 1818, Macaristan Akademisi Kütüphanesi (URL5)

Yöre başta Sarı Saltuk, Kolonizatör Yesevi Dervişleri ve Bektaşiler, Evladı Fatihan ve Karaman Sürgünleri, Bogomil, Kazıklı Voyvoda, Kont Drakula, Gagavuz ve Pomaklar, Deliorman, Adakale, Sabatay Sevi, Simavna Kadısı Şeyh Bedrettin, 1876 Osmanl1-Rus Harbi/93 Harbi, 1912 Balkan Harbi Göçmenleri, Cumhuriyetin Yüzellilikleri, Kazım Karabekir Paşa'nın Ermenileri, Kırım Tatarları gibi tarihimize yabancı olmayan başlıklar altında bilinen - bilinmeyenleri ve anlatılan - anlatılmayanları ile Anadolu Selçuklu, Anadolu Beylikleri ve Osmanlı dönemleri ile uzaktan yakından ilişkilidir. Bu konuda Aydın Uğurlu, yöredeki toplum hareketliliği konusunda şu bilgileri yazmıştır: "Orta Çağ boyunca pek çok toplum grupları, Anadolu'ya, Anadolu dışına yahut bir başka yere, kâh istekli, zaman zaman da zorunlu göç etmişlerdir. Bizanslılar Trakya'dan gelen Kumanları İznik ve Bursa çevresine, Doğudaki Ermenileri Kapadokya'ya yerleştirmişler, Venedik ve Cenevizliler birbirlerinin ardı sıra Anadolu ticaret merkezlerine yerleşmişlerdi” (1987: 3).

Transilvanya, uzun bir süre boyunca Doğu ve Batı kültürlerinin buluşma noktası olmuştur. Yüzyıllar boyunca bölgede süren Romanya nüfusunun çoğunluğunu oluşturan kültürel ve dini buluşma noktası olarak kültürler alaşımını oluşturan bir bölge olarak devam etmiştir. Transilvanya, 1526 yılında Yıldırım Bayezid zamanında Osmanlı idaresine katılmıştır (Ionescu, 2005: 30).

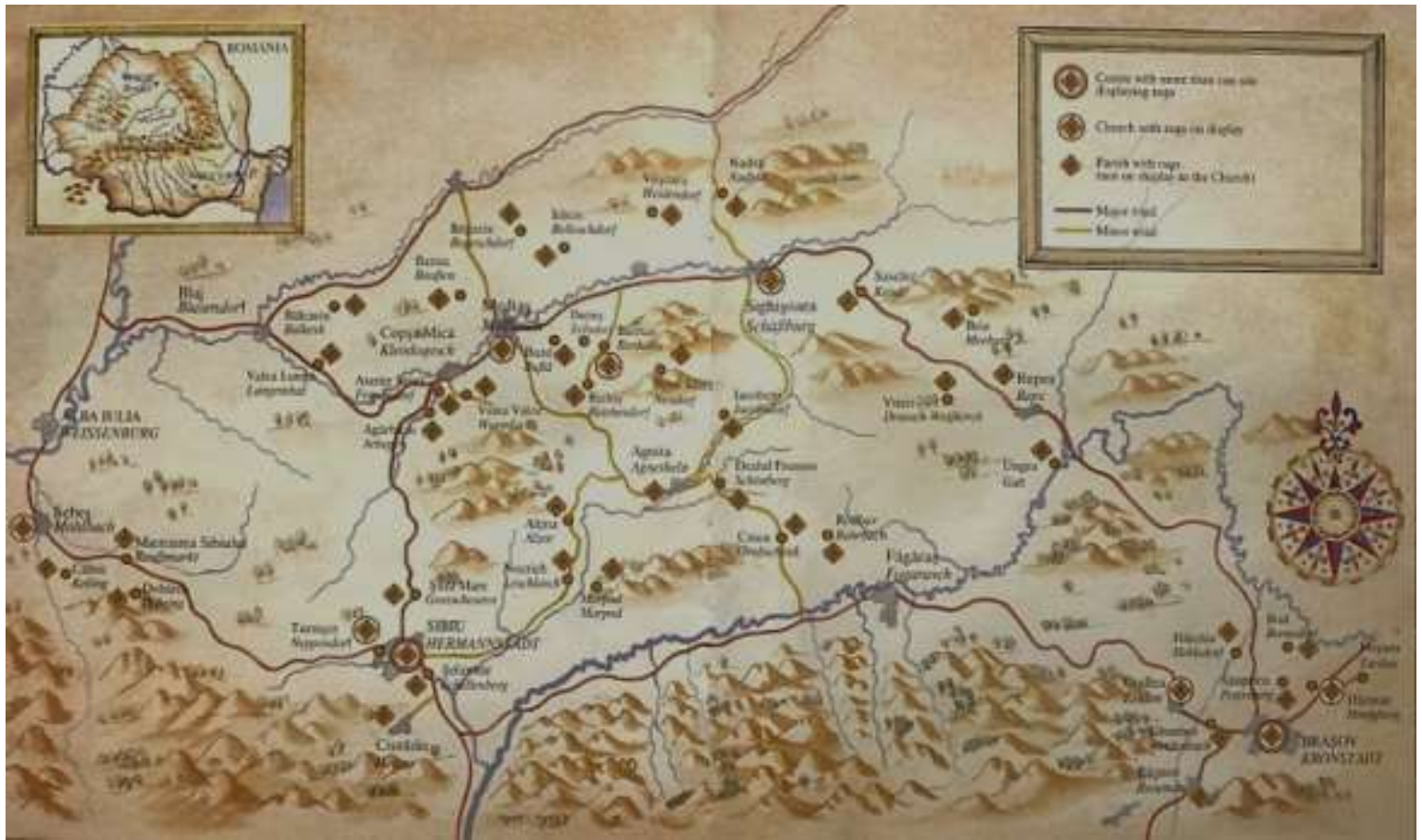

Harita 1. Transilvanya'daki Osmanlı Halılarının bulunduğu müze, kilise ve yerler ile ana yol ve ara yol rotaları (Kaynak: Ionescu, 2005: 174-175) 
Cluj'daki geç dönem arşivleri yanı sıra Braşov ve Sibiu'daki Sakson arşivleri, Transilvanya ve Osmanlı İmparatorluğu arasındaki yoğun ticaret aktivitelerinin oluşumundan kısmen bahsetmektedir (Ionescu, 2005: 25). 16. yüzyıl ile 18. yüzyıl zaman aralığında genellikle Müslümanların namazlık boyutunda dokumuş olduğu Batı Anadolu kökenli halılar, Transilvanya bölgesinde bulunan Sakson/Alman ve Macar Protestan/Lutheryan kiliselerinde çok iyi korunmuş halde 1933 yılında bulunmuştur. Bu halılar, Siebenbürgen Halıları veya Transilvanya Halıları olarak adlandırılmaktadır (Hubel, 1972: 63-324).

Marco Polo ve Magripli İbn Said; Anadolu Selçukluları, Anadolu Beylikleri ve Moğol döneminde, Anadolu kırsal kesiminde dokunan Yörük ve Türkmen halılarının yabancı ülkelere satıldığını yazmışlardır. Anadolu Türkmen ve Yörük halıları, Batı ülkelerinde prestij nedeni olmuş, Kurt Erdmann gibi araştırmacılar bu halıların Avrupa Rönesans dönemi sanatçılarının tablolarında resmedildiğini yazmalarından sonra ise bu tabloların araştırılmasına neden olmuştur.

$\mathrm{Bu}$ dönem sonrasında Avrupa tablolarında resmedilen Anadolu halıları hakkında birçok aceleye getirilmiş mükerrer makale ve yayın oluşturulmuştur. Müslümanların Tanrıya ibadetlerinde kullandıkları taşınması kolay, namazlık boyutundaki Batı Anadolu'da dokunmuş, Osmanlı ticareti ile Transilvanya'da yaşayanlara satılmış halıların; Macaristan, Romanya, Bulgaristan ve Moldova'da dokunduğunu ileri sürecek kadar önyargılı olan yazılarda ve bu halıların Romanya'da ticari mal olarak depolandığı da yazılmıştır (Ionescu, 2005: 33).

$\mathrm{Bu}$ konuda başka bir varsayım ise; bu halıların Osmanlı askerlerinin ibadet amacıyla yanlarında taşıdıkları namazlıklar olduğu ve Transilvanya'dan ayrılırken bu bölgede bıraktıklarıdır (S. Ionescu, görüşme, 9 Ekim 2019). Ancak Stefano Ionescu'nun uzun süredir yaptığı araştırmalar sayesinde, bu halıların kilise kayıtlarından Osmanlı-Türk halıları olduğu ve Batı Anadolu'dan Transilvanya'ya ticari mal olarak getirildiği anlaşılmıştır. "Koleksiyonların Transilvanya'da toplanmasının nedeni, halıların işlevlerine, beğeni kazanmalarına, özellikle de kilise vakıflarının mülkiyetinde olmalarına bağlı bir dizi koşuldur” (Ionescu \& Kertesz, 2007: 33).

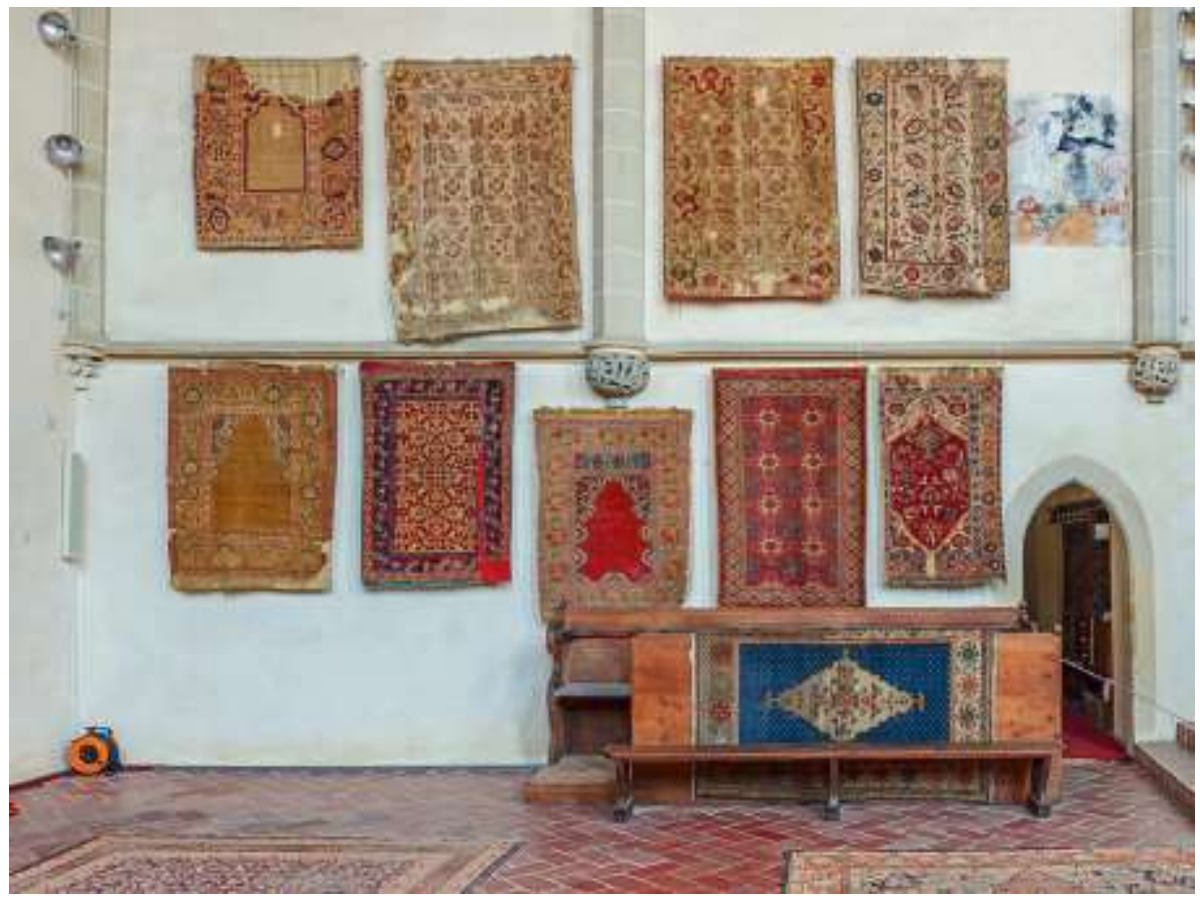

Resim 5. Mediaş St. Margaret Kilisesinde sergilenen halılar (Kaynak: Boz, 2015: 82) 
Transilvanya Protestan Kiliselerinde bulunan Osmanl1-Türk Halıları hakkında yayınlar nispeten az ve birçoğu bu halıların kökeniyle ilgilidir. Müslüman inancında olanların, tanrıya yakarış için kullandıkları küçük boyutlu bu halılarla ilgili aceleci, fantazi yaklaşımlar ile yazılan ön yargılı başka amaçlar taşıyan makale ve yayınlar da vardır.

Bu konuda yöre kökenli, İtalya'da yaşayan, araştırmacı-yazar; Stefano Ionescu 9 Ekim 2019 tarihinde İstanbul'da, Romanya Kültür Merkezi'nde "Anadolu'dan Başarılı Bir Grup: Transilvanya Halıları" başlıklı konferansında, Transilvanya Halıları üzerine yaptığı araştırmalarını açıklayan ve tıpkı üretimlerin sergilendiği etkinlikte, Romanya, Macaristan ve diğer ülkelerdeki müze, koleksiyon ve Transilvanya kiliselerindeki Transilvanya halıları hakkında bilgiler vermiştir. Konferansında, Transilvanya kiliselerinde Osmanlı halıcılı̆̆ının altın dönemi sayılan 16. ve 17. yüzyıllardan günümüze ulaşan, genellikle namazlık boyutlarında, Holbein, Uşak, Lotto, Selendi ve Transilvanya tipi olarak sınıflandırılan yaklaşı 400 civarında halı bulunduğunu söylemiştir. $\mathrm{Bu}$ yakarış halılarının bulunması ve günümüze ulaşmasını ise kültürlerarası bir uzlaşımının göstergesi olduğunu vurgulamıştır. Bu durumun yakın zamana kadar sıklıkla yanlış ya da mümkün olmayacak köken teorileriyle açıklanmaya çalışıldığını da belirtmiştir. Aralarında Amerikalı C. G. Ellis'in de bulunduğu bazı halı uzmanlarının, bu halıları sıklıkla yanlış ya da mümkün olmayacak köken teorileriyle, Anadolu dişında dokunmuş olabileceğini iddia etmişlerdir (S. Ionescu, görüşme, 9 Ekim 2019). Stefano Ionescu, bahsettiği bilgileri, ilk basımı 2005 ve ikinci basımı 2007 yıllarında yapılan "Antique Ottoman Rugs in Transylvania" (Transilvanya'da Antik Osmanlı Halıları) adlı kitabında da yazmıştır.

\section{Transilvanya'da Halı Ticareti}

Transilvanya'daki Türk halı ticaretinde üç dönem vardır: 1450'den 1541'e kadar olan süreçte Transilvanya bir eyalet haline geldiği ilk dönem; 1627 'de Türk üretimlere gümrük vergileri başladığında ve Türk ürünlerine el konulduğunda otoriteler tarafından girişim olmaksızın yapılmış ticaret ve üçüncü dönem önce Sibiu ve sonrasında Braşov'da 17. yüzyıl ortasından başlayarak Türk ürünlerinin ticaretini Yunan ticaret şirketlerinin tekel olarak devraldığı dönemdir. Bu dönemde halı ticareti, 18. yüzyıl sonuna doğru kesintiye uğramıştır (Ionescu, 2005: 26-31).

1456'da Fatih Sultan Mehmet zamanında Moldovyalı tüccarlar İstanbul'a deniz aşırı ticaret ile alışverişlerini yapmışlardır. Transilvanya'daki 1462-1464 yılları arasına tarihlenen en eski belge Braşov'dadır ve halıların direkt olarak sevk edildiği yazmaktadır. Transilvanya-Osmanlı ticareti rotasında halılar, panayır ve pazarlar için getirilmiş, gümrük belgelerinde geçen halılar sıklıkla listelenmiş, ürün miktarı ve ücreti gümrük yetkilileri tarafından kaydedilmiştir (Ionescu, 2005: 2627).

1526'da Mohaç Savaşı, Transilvanya halı ticaretinde ikinci dönemin başlamasına neden olmuştur. Macaristan topraklarının çoğu Osmanlı İmparatorluğu'na bağlı bir paşalık haline gelmiş ve 1541'de Budapeşte Transilvanya'nın başkenti olmuştur (Ionescu, 2005: 30).

Türk, Valensiyalı ya da Transilvanyalı tüccarlar, Batı Anadolu'dan getirilen ve İstanbuldaki halı tüccarlarından aldıkları bu halıları; İstanbul'dan başlayarak Tuna doğrultusunda Burgaz'a ya da Edirne boyunca Avrupa'ya götürmüşlerdir. Bu güzergâh, Orta Avrupa için başlıca rota olmuştur (Ionescu, 2005: 27-28). O dönemde, İtalyan hükümetleri ve Osmanlı İmparatorluğu ile yaptıkları anlaşmalar sonucunda, Batı Anadolu halıları ve diğer Türk ürünleri; Venedik, Cenova, Pisa ve Floransalı tüccarlar tarafindan Avrupa'ya deniz yoluyla getirilmiştir (Ionescu, 2005: 27).

19. yüzyılda Transilvanya'daki bu halılar yabancı halı satıcılarının dikkatini çekmiştir. Şehirlerdeki asilzadeler başta olmak üzere Romanyalılar ellerindeki halıların çoğunu Yunan tüccarlara satmışlardır. "Halı Avı Dönemi” olarak isimlendirilmiş bu süreç, 19. yüzyılın ikinci yarısında başlamış, bölgedeki çok sayıda halı yok pahasına satılmış ya da çalınmıştır. Bu dönemde miraslarına saygı duyan Saksonların kültür hazinesi olarak gördügü halıları, kilise depolarına 
kaldırmış oldukları tahmin edilmektedir. Alınan tedbirlere karşın St. Margaret Kilisesinden dokuz halının çalındığ bilinmektedir (Ionescu, 2005: 12; Boz, 2013: 101). Sadece Luteryan kiliselerde korunan çok sayıda halı grupları hayatta kalmıştır ve bu halılar alternatif periyotlarla değiştirerek bina içlerini dekore etmektedirler (Ionescu, 2005; 40).

Yüzlerce örneğin 25 yıldan daha az bir süre içerisinde satılmasına karşın, Transilvanya'da çok sayıda halının günümüze niçin ve nasıl hayatta kaldığını açıklayan iki anahtar vardır. İlki; Romanya'daki Sakson aileler ellerindeki klasik Osmanlı halılarını satmayıp kiliselere bağışta bulunmayı tercih etmişlerdir. İkincisi ise Saksonlar kiliselerdeki halıların bakımına büyük yardımda bulunmuştur. $\mathrm{Bu}$ nedenle çok sayıda tarihi Türk halısının korunmasına neden olmuşlardır. Bazı papazlar halıların 350 yıl üzerinde olduğunu söylemiştir (Ionescu, 2005: 31). Transilvanya'da günümüz Evangelist kiliseler, kilise depoları ve müzelerinde halen 15. yüzyıl ikinci yarısından 17. yüzyıl sonuna kadar olan süreç içerisinde yaklaşık 380 halı ve halı parçası halen korunmaktadır (Ionescu, 2005: 41-45). Bu bölgede bulunan klasik Türk halı tiplerinin neredeyse tamamı küçük boyutlardadır.

20. yüzyılda Transilvanya kiliselerindeki Batı Anadolu halılarına ilgi giderek artmıştır. Bu dönemde Romanyalı usta halı tamircisi ve halı üreticisi olan Theodor Tuduc, Braşov yakınında bir atölye kurmuş ve 1930-1960 yılları arasında Transilvanya kiliselerindeki halıların çok sayıda kopyalarını dokutturmuştur. Hatta o dönemde atölyesine Kayseri'den bile dokuyucular getirtmiştir. Orijinallerinden ayırt edilemeyecek biçimde olan yüzyılın halı sahtekarı Tuduc'un sahte halıları, müze, koleksiyoner ve müzayede evlerindeki halı uzmanlarının bile farkedemediği şekilde eskitmiştir. (Ionescu, 2010: 1; 2005: 212-217). Tuduc'un sahte kopya halıları, aynı zamanda Anadolu halılarının sanatsal değerinin kanıtı olmuştur.

\section{Günümüze Ulaşan Beyaz Zeminli Akrep Motifli Selendi Halıları}

"Selçuklular döneminden itibaren; Konya, Bursa, Uşak, Bergama ve İstanbul bölgelerinde merkez atölyeler kurulmuş ve bu atölyelerde kendi karakterini yansıtan, genellikle Anadolu Yörük halıları diye bilinen çeşitli üsluplara sahip halılar dokunmuştur. 17. yüzyılda Uşak halıları ününü kaybetmeye başladığı dönemlerde, Batı Anadolu bölgesinde Gördes, Kula, Bergama ve Milas, İç Anadolu bölgesinde Lâdik, Kırşehir ve Mucur halıları ün kazanmıştır” (Akpınarlı vd., 2020: 34).

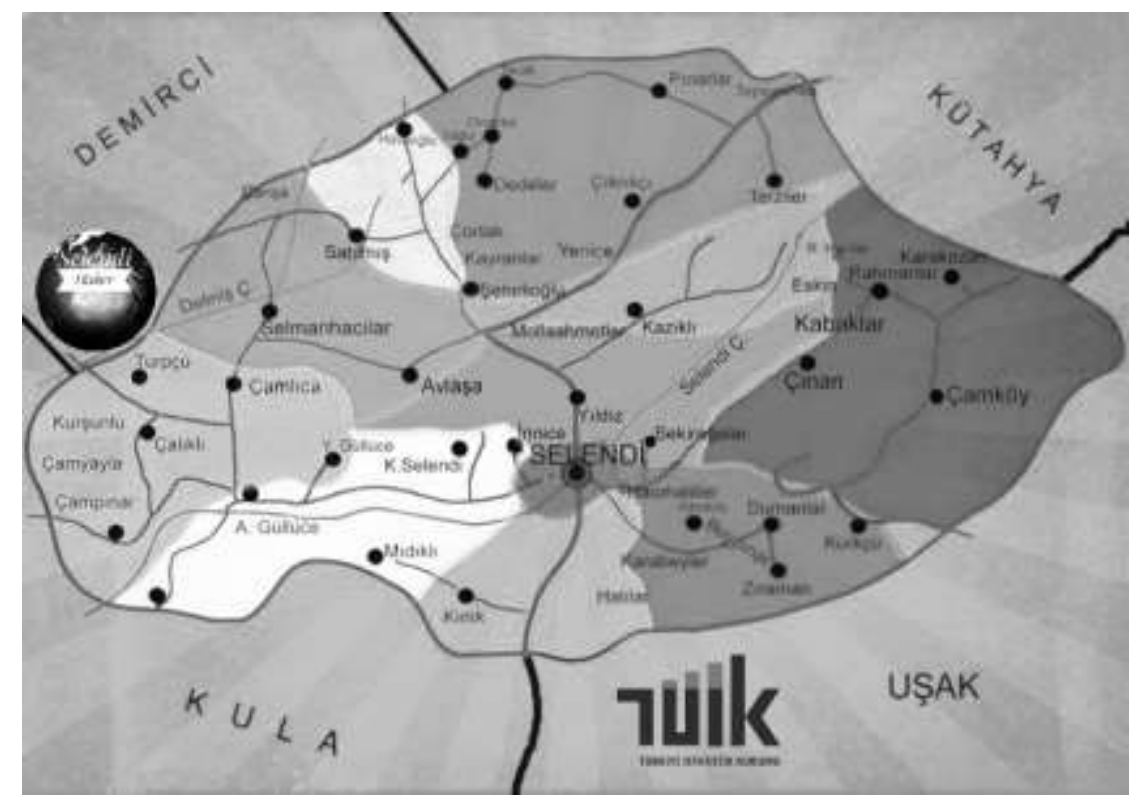

Harita 2. Manisa ili Selendi ilçesi ve köylerinin haritası (URL6)

Turkish Studies, 16(4) 
Günümüzde Ege Bölgesi Manisa iline bağlı olan Selendi, Gediz Nehri’nin Selendi Çayı'ndan adını almıştır. Selendi, Batı Anadolu'da Uşak, Kula, Manisa, Demirci, Kütahya gibi halı merkezlerine komşudur. 19. yüzyılın ilk yarısına kadar Selendi'de boyalık tarlası ekildiği bilinmektedir (Ateş, 2014: 65). 1907-1908 yılları arasında kurulan Londra merkezli The Oriental Carpet Manufacturers Limited, bu bölgede de malzemesi ve desenini vererek halı dokutturduğu için, yöredeki bazı geleneksel halı desenleri ve geleneksel dokuma kültürünün unutulmasına sebep olmuştur. Selendi'nin merkez ilçesinde günümüzde halen dokumacılıkla ilgili Çıkrıkçı ve Halılar mahallelerinin olduğu bilinmektedir (Ateş, 2014: 2-15).

16. ve 17. yüzyıllar Anadolu halıcılığı için önemli yıllar olmuştur. Bu dönemde Batı Anadolu'da birbirinden çok farklı grupta halılar dokunduğu bilinmektedir. Özellikle Uşak ve çevresinde dokunan Uşak Halıları olarak tanımlanan bir halı grubu vardır.

Bu gruptan beyaz zeminli Uşak halılarının motif ve desenleri inceldiğinde; üç benekli ve çintemanili, kuşlu/kargalı ve akrep motifli halılar olmak üzere genel olarak üç gruba ayrılmaktadır (Franses, 2007: 67-69). Ülkemizde beyaz zeminli akrep motifli Selendi halılarından örnek olmadığı için çoğunlukla yabancılar tarafından araştırılmıştır.

Transilvanya' da günümüze ulaşmış halıların dokuma yapısı, ilme tipi, iplik boyamaları gibi karakteristik özellikleri diğer tüm Anadolu Türk halılarının özellikleri ile aynıdır. Çok sayıda uzman onların Batı Anadolu'da Uşak, özellikle Selendi'de dokunduklarına hemfikirdirler (Pásztor 2007: 106; Ionescu, 2007: 110-111).

Dönemin Avrupa resimlerinde beyaz zeminli akrep motifli Selendi halısı betimlenmiş tablo bulunmamasına karşın, uzmanlar halıların tarihlendirmelerinde beyaz zeminli kuş motifli Selendi halılarından yararlanarak ve onlardan örnek alarak yorum yapmakta, iki grubu da aynı zaman dilimine yani 17. yüzyıl ortalarına tarihlendirmektedirler (Erdmann, 1965: 54; Batári, 1986: 201202; Pásztor, 2007: 106; Ionescu, 2007: 110-111; Boz, 2013: 133). 


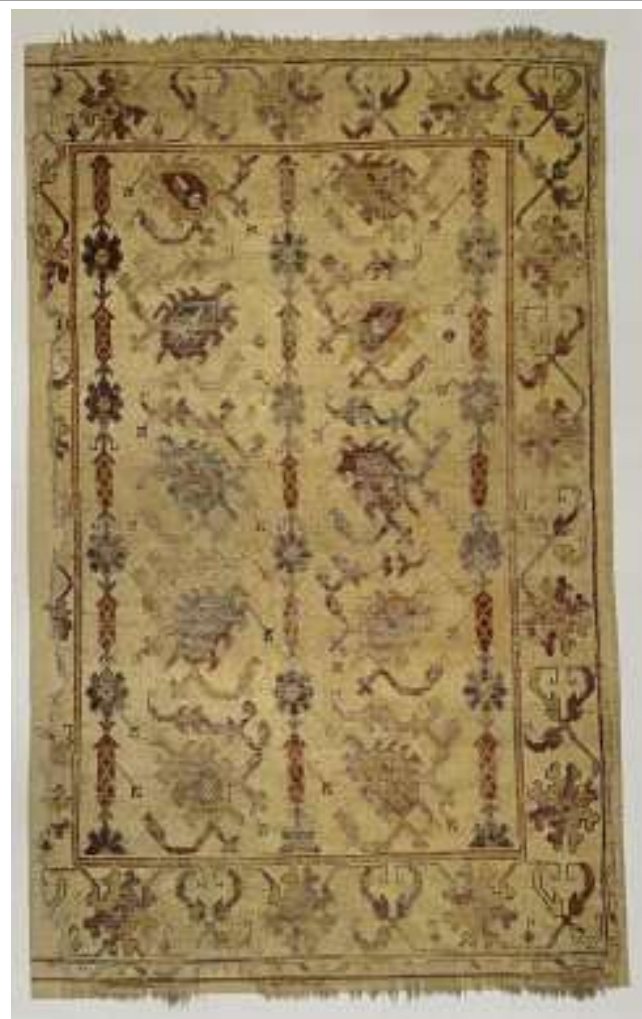

Resim 6. Beyaz Zeminli Akrep Motifli Halı 17. yüzy1l ortas1, 116x191 cm, Kara Kilise, Envanter no. 373, Braşov (Ionescu, 2007: 110)

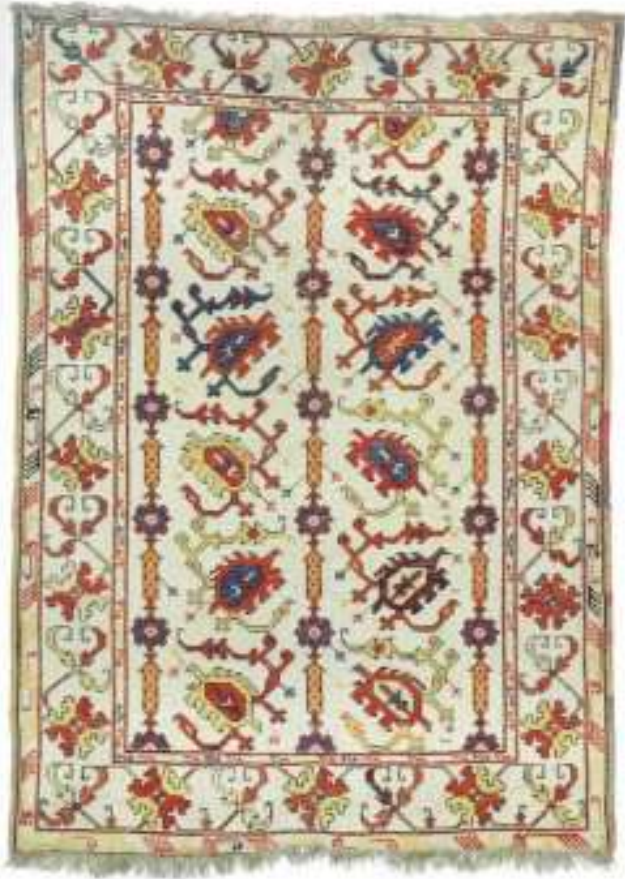

Resim 8. Beyaz Zeminli Akrep Motifli Halı 17. yüzy1l ortas1, 116x191 cm,

Budapeşte Uygulamalı Sanatlar Müzesi, Envanter no. 7968, Budapeşte (Pásztor, 2007: 111)

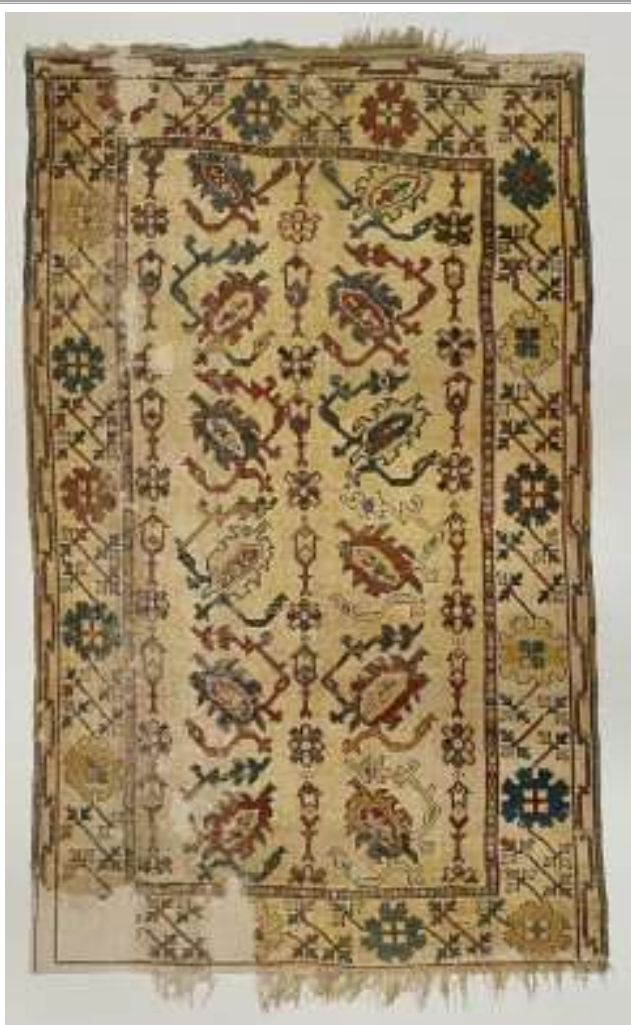

Resim 7. Beyaz Zeminli Akrep Motifli Halı 17. yüzy1l ortas1, $112 \times 178 \mathrm{~cm}$,

St. Margaret Kilisesi, Envanter no. 111, Mediaş (Ionescu, 2007: 111)

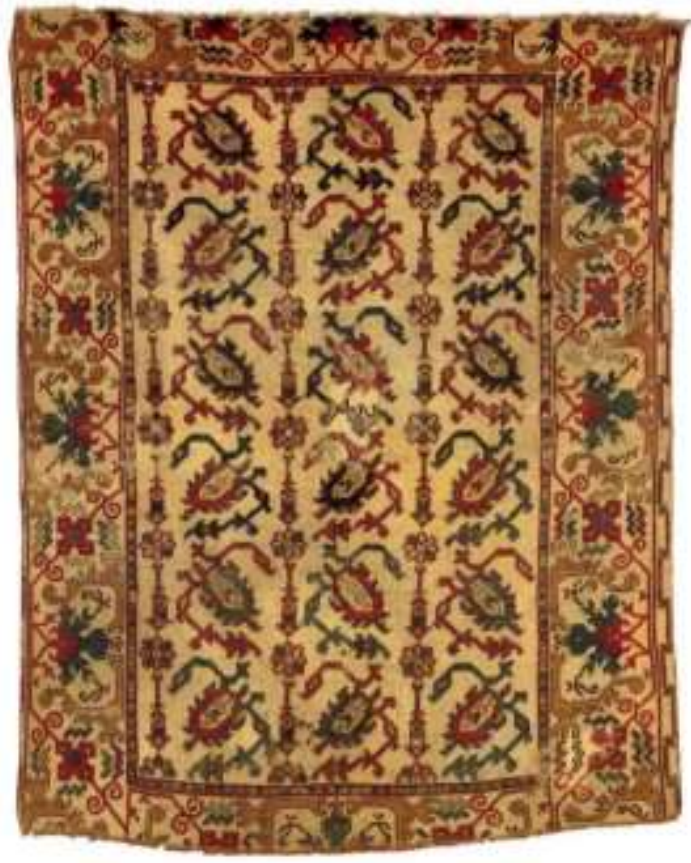

Resim 9. Beyaz Zeminli Akrep Motifli Halı 17. yüzyıl ortası, boyutları bilinmiyor, Keir Koleksiyonu, Londra (John Taylor, URL7) 


\section{Malzeme}

Halılarda dönemin ve yörenin özelliği olarak çözgü, atk1 ve ilmelerinde malzeme olarak yün kullanılmıştır.

\section{Teknik}

Halıların dokunmasında Anadolu'nun kendine has halı ilmesi karakteri olan "Türk İlmesi” / "Gördes İlmesi” kullanılmıştır.

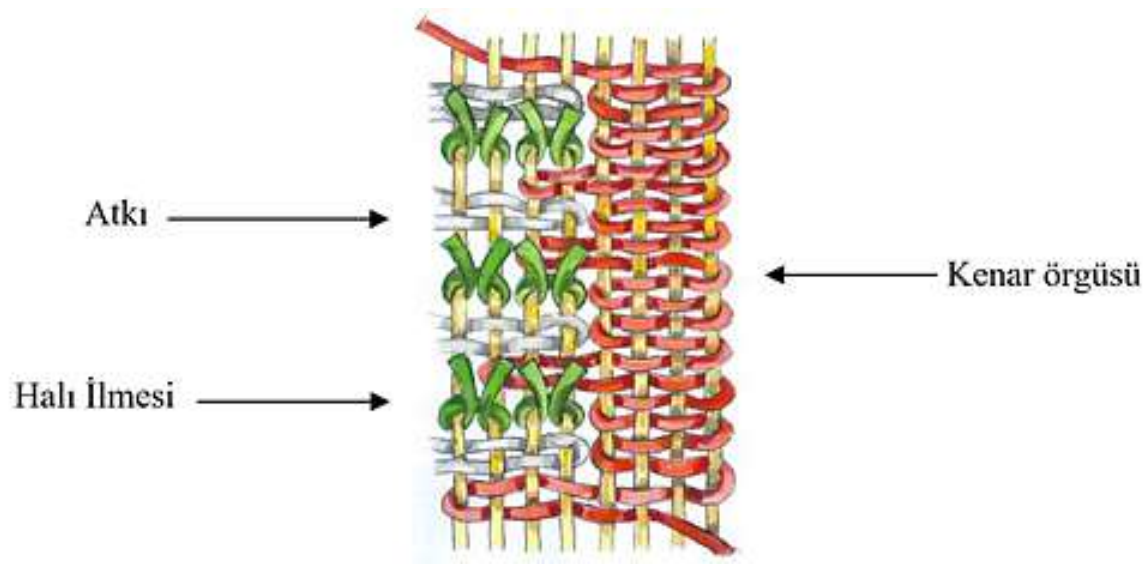

Çizim 1. Çözgü, atk1, kenar örgüsü ve halı ilmeleri (Çizim: Servet Senem Uğurlu, 1999)

\section{Renk}

Halıcılıkta renklendirme işlemi kullanılan malzemenin türüne göre değişmekte ve farklı boyama teknikleri kullanılmaktadır. Boyama; tekstil lifinin türü, şekli, boyarmaddenin kimyasal özelliğine göre değişen, 1sı ve su devinimi yardımıyla mekanik ya da kimyasal yöntemler kullanılarak belirli süre içerisinde boyamada kullanılan boyarmadde moleküllerinin boya banyosundaki elyafa geçerek bağlanmaları ile yapılan renklendirme işlemidir (Uğurlu, 2020: 3132).

Beyaz zeminli akrep motifli Selendi halılarının en önemli özellikleri, halı ortalarındaki zemin ile tüm bordürlerinin zemin renkleri; doğal beyaz yün rengindedir. $\mathrm{Bu}$ renk, bazı araştırmalarda beyaz, bazı araştırmalarda ise fildişi rengi olarak belirtilmiştir. Halı ortalarındaki zemin renginin doğal beyaz yün rengi olduğu anlaşılmaktadır. Bu renk, zamanla doğal beyaz renginden fildişi rengin tonlarına dönüşmüştür. Beyaz zeminli akrep motifli Selendi halılarındaki motiflerde ise kırmızı ve koyu kırmızı, sarı, koyu mavi ve siyah renkler kullanılmıştır.

\section{Akrep Motifi ve Özellikleri}

Türkmen ve Yörükler, İlkçağdan bu yana doğal yaşam çevrelerinde gördükleri hayvan ve bitkileri izleyerek dokumalarına motif olarak aktarmışlardır. Ayrıca sanatlarında da bu motifleri sıklıkla kullandıkları görülmektedir. Kilim ve keçe gibi geleneksel tekstiller, malzeme ve teknikleri nedeniyle yüzeylerinde akrebin zorlanarak dolaştıkları bilinmektedir. Topak Ev / Yurt ve Kıl çadır / Karaçadır gibi mekanlarda zemine keçe ve kilimler kullanılmış, hatta çok sayıda akrep motifi bu geleneksel tekstillerin üzerinde görselleştirilerek dokunmuştur. $\mathrm{Bu}$ nedenle dokumalar koruyucu görevindedir. Anadolu insanı, çevresinden gelecek tüm zararlara karşı yaşadığı deneyimler ve oluşturdukları geleneksel inançları ile kendisini korumaktadır. Örneğin Anadolu insanı akrep, yılan, çıyan gibi kendisine zarar verebilecek sürüngenlere karşı, dokumalarının ortalarında ya da dış sularında akrep motifini kullanmışlardır (Erbek, 2002: 154).

Anadolu dört mevsimin aynı anda yaşandığı bir coğrafi bölgedir ve biyolojik çeşitliliğgi ile dikkat çekmektedir. Dağlık, rutubetli ya da kurak olan her yerde ve yörede bulunan akrep, intihar 
eden tek hayvan olduğu için özgürlük simgesi olmuştur (Ersoy, 2000: 449). Kutsal ve kara gücü temsil eder. Onun stilize olarak resmedilmesi, yalnız acı veren sokması yanında kendisini negatif güçlerden koruması içindir. Kafkaslarda Yamut aşiretinde, cesaretin sembolü olarak kabul edilir. Kötülüklerden uzaklaştırıcı olarak kullanılır (Iten-Maritz, 1991: 298).

İnsanlar akrepten korkmuş ve kendisini ondan korumak istemişlerdir. Buna rağmen akrep, insanlar tarafindan daima merak edilen bir hayvan olmuştur. Geceyi seven akrepler, beslenmelerini de gece yaparlar. Akrep motif olarak incelendiğinde ise; yaşam ile şeytanın ruhunu simgelediği bilinmektedir (Gezgin, 2007: 16-17). Anadolu halı, kilim, dokuma ve işlemelerinde de akrep motifi sıklıkla görülmektedir.

\section{Anadolu'da kutsal olarak kabul edilen akrebin kendini tanımlaması şöyledir: \\ "Ben ne doğal ruhum ne de şeytan. Bana dokunan herkese ölüm getiren bir yaratığım. İki boynuzum ve sağdan sola savurduğum bir kuyruğum var. Boynuzlarımın adı acımasızlık ve nefret, kuyruğum ise hançerdir. Ben sadece bir kez doğururum. Diğer yaratıklarda bereketin simgesi olan doğurganlık, benim için ölüm işaretidir." Sürekli açıkta ve ona dokunacak kimseye ölüm şırıngalamaya hazır bir zehir kesesi ile biten kuyruğu, her an öldürmek için pusuda bekleyen kötü niyetin ve nedensiz kavganın somut bir simgesidir" (Erbek, 2002: 154).}

Tarihsel süreç içerisinde uygarlık tarihi boyunca akrebe çeşitli anlamlar yüklenmiştir. Akrebin tanrısal olduğu, kutsallık taşıdığı, hatta şifa dağıtan bir mucize olduğu düşünülmüştür. Bazen kralların hazinesini koruyan bir bekçi olan akrep, genellikle hainlik ve kötülüğün sembolü olmuştur. Ayrıca akrep ve güneş arasındaki bağlantılar mitoslara aynen yansımıştır. Antikçağ Anadolu Mitolojisinde Tanrıça Artemis'in gönderdiği bir akrep Tanrı Poseidon'un oğlu Orion'u topuğundan sokmuştur. Artemis akrebi bir burca dönüştürerek ödüllendirmiştir. Orion'da sonrasında burç olmuştur. Bir diğer mitoloji söylencesi ise, Güneşin oğlu Phaethon'un babasının arabasını sürerken Zodyak hayvanlarını görünce korkuya kapılarak yolunu şaşırması ve karşılaştığı akrep tarafindan sokularak zehirlenmesini içermektedir (Grimal, 1997: 580-581).

Akrep, Sami tanrıçası İşhara'nın kutsal hayvanıdır. Astronomide akrep burcunu simgeleyen Tanrıça İşhara'dır. Ayrıca gökbilimine meraklı Babil'de Scorpius takımyıldızına "akrep" adı verilmiş̧ir. Akad, Asur, Babil uygarlıklarının mitolojilerinde ortak kahramanlardan biri "akrep adamlar"dır. Akrep adamlar, ilk olarak Babil'in yaratılış mitosunda bahsedilmektedir. Sümerlerde Utu, Akadlarda Şamaş olarak bilinen güneş tanrısının başlıca yardımcıları akrep adamlardır. Akrep adamlar genellikle gökyüzü kapılarını korumaktadırlar. Gılgamış Destanında ise kadın ve erkek iki akrep insandan bahsedilmektedir (Gezgin, 2007: 17-18).

Zıtlıklar dini olan Zerdüştlükte, akrebin yaratılışı, mit ile açıklanmaktadır. İyi-kötü, güzelçirkin, 1şık-karanlık gibi tüm zıtlıkları kendisinde barındıran zıtlıkların birliği Zurvan, sonsuzluktur. Zurvan, bir oğul sahibi olmak isterken iki oğlu olur. İlk oğul Ehrimen karanlık, kötülük ve ölümün; ikinci oğlu Hürmüz ise aydınlık, iyilik ve yaşamın tanrıları olmuştur. Zurvan'ın sevdiği ve oğlu olarak desteklediği Hürmüz, Ehrimen'i karanlıklara gömerek dünyayı yönetirken 3000 yıl sonra Ehrimen uyanarak kosmosta düzensizlik ve kaosu başlatır. Karanlık çöken dünyada Ehrimen, kendisi gibi kötü ve akrep gibi ölümcül yaratıklar oluşturur (Gezgin, 2007: 18-19).

Anadolu halk inanışlarında akrep, sirke ve sarımsak karışımından yapılmış merhemin baş ağrısına iyi gelerek hastaya şifa verdiği ve bazı insanları akrebin sokmayarak onların göğsünde dolaşarak onlara sevgi beslediği düşünülmektedir. Halen Ege ve Akdeniz'de eski Rum evlerinin kap1 ve pencereleri ile Güneydoğu Anadolu'da taht adındaki ranzaların renkleri çivit mavisidir. Yöre insanları, akrebin mavi rengi ateş gibi gördügü için yaklaşmadıklarına inanmaktadır (Gezgin, 2007: 19). 
Hatta Osmanlı sultanları için yapılan tılsımlı gömleklerde Mikail, Cebrail, Azrail, İsrafil gibi dört meleğin adı sıklıkla kullanılmıştır. Bu isimlerin yanına akrep / seretan resmi çizilmiştir (Tezcan, 2011: 24).

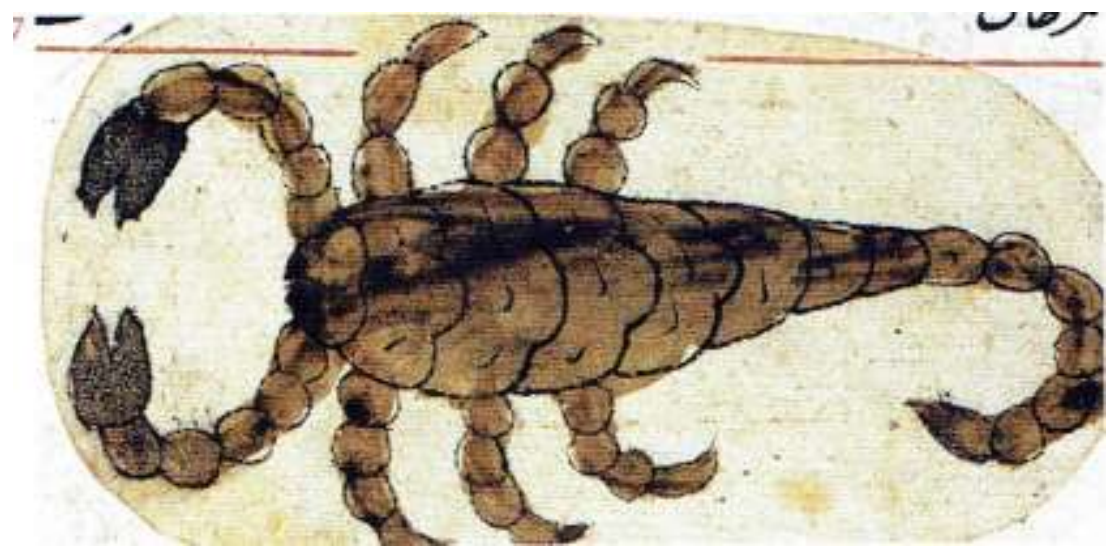

Resim 10. T11sımlı gömleğin üzerindeki akrep motifi (Tezcan, 2011:24)

Osmanlı Adet, Merasim ve Tabirleri başlığı altında halk inanışlarını yazan Abdülaziz Bey, yılan, akrep ve benzerleri hayvanlardan korunmak için yapılan "Şerbetlenmek" kavramıyla ilgili verdiği örnek şöyledir: Kadriye ve Rifaîye şeyhleri şerbetlenmek isteyen müritlerinin öncelikle diz üstüne çöktürdükten sonra içinde zeytinyağı bulunan fincanına dua ederek üfler, ağzına aldıktan sonra fincana zeytinyağını tükürür ve talip olarak içen müridini artık zehirli hayvanların sokmayacağına ve bu hayvanlardan zarar görmeyeceğine inanılırdı. (Arısan ve Arısan Günay, 1995: 20-21).

Halk arasında özellikle Rifâiye tarikati şeyh ve mensupları tarafından, yılan akrep gibi sürüngenlerin sokmalarını önlemek için, "akrep efsunu" adı verilen sürüngenin uyutularak etkisiz hale getirilmesi sağlanır. Özellikle bu tarikat, akrebi kovmak için akrep resmi çizmişlerdir. Ancak akrep /seretan şeklinin astroloji ile bağlantılı olduğu sanılmaktadır (Tezcan, 2011: 24).

\section{Akrep Motifli Beyaz Zeminli Selendi Halılarında Motifler ve Desen Kompozisyonu}

İslam inancına göre, namaz vakti geldiğinde, insanın bulunduğu yer ibadet yeri olarak kabul edilmektedir. Bu Türklerin göçebe kültürüne çok uygun bir inanç şartıydı. İslam inancını kabul eden Türkler, ibadetlerini yapabilmek için kolayca taşınabilir boyutlarda halı ya da kilim namazlıkları dokumuşlardır. Bu dokumalarda motifler incelendiğinde; Türklerin inanç, inanış, kültür, gelenek ve hayatlarından izler taşıdığı görülür.

Bunlar, yakın çevre ya da geçmiş kültürlerden gelen sembolik ve felsefi anlamlar taşımaktadır. Halı sularıyla başlayan bu örnekler, somut ve soyut değerler ile geometrik temelli motifler kullanılarak zenginleştirilmiştir. Namazlık yüzeyleri cennet bahçesi görünümünde çeşitli motifler ile süslenmiştir (Uğurlu, 2020: 3123-3149). 


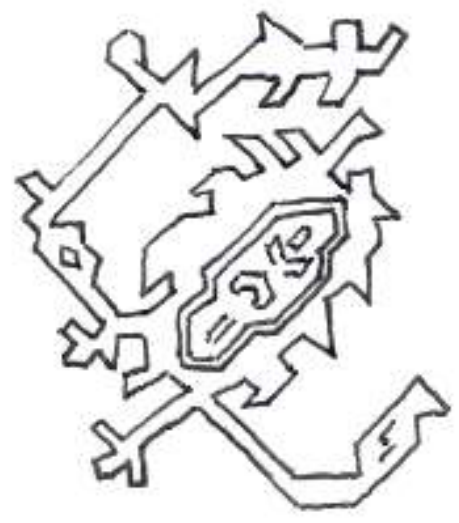

Çizim 2. Akrep motifinin dokumadan kaynaklanan farklı görünümü (Çizim: Servet Senem Uğurlu, 2021)

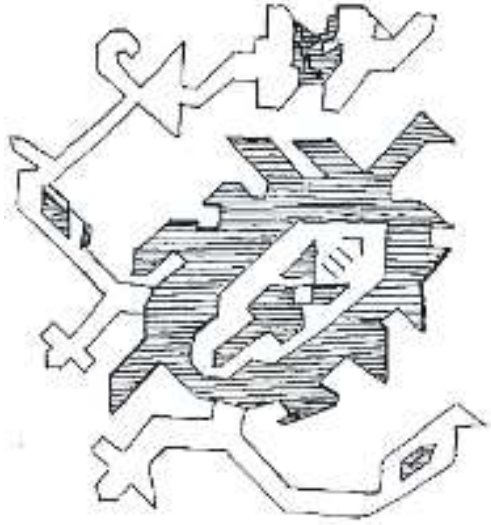

Çizim 3. Akrep motifinin dokumadan kaynaklanan farklı görünümü (Çizim: Servet Senem Uğurlu, 2021)

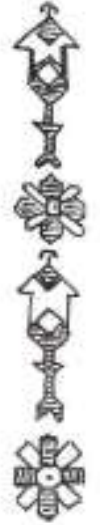

Çizim 4. Akrepli halıların ortasında sütunlar olușturan motif dizisi (Çizim: Servet Senem Uğurlu, 2021)

Beyaz zeminli akrep motifli Selendi halılarında çok farklı motifler kullanılmıştır. Halı sularında genellikle bir geniş ve en az bir dar olmak üzere iki ya da üç adet halı suyu vardır.

Batári ve Dall’Oglio, beyaz zeminli akrep motifli Selendi halılarındaki motifleri, "Yengeç" olarak isimlendirmişlerdir. Hatta bu motifin kuş motifinden yararlanılarak oluşturulmuş olabileceğini düşünmüşlerdir (Batári, 1986: 199; Dall’Oglio, 1986; 189).

$\mathrm{Bu}$ halıların Avrupa resimlerinde resimlendiği örnek olmadığı için, halıların tarihlendirmelerini, Pásztor ve Ionescu; Beyaz Zeminli Kuşlu Selendi Halılarını dikkate alınarak yapmışlar ve halıları 17. yüzyılın ortalarına tarihlendirmişlerdir (Pásztor 2007: 106; Ionescu, 2007: 110-111).

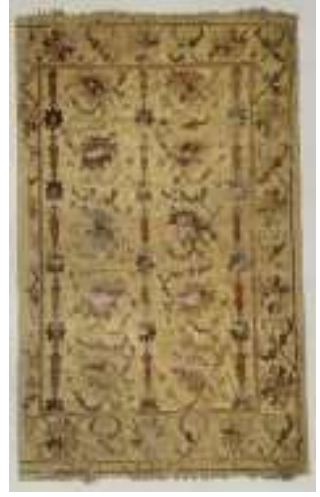

Resim 11. Kara

Kilise'deki halı (Ionescu, 2007: 110)

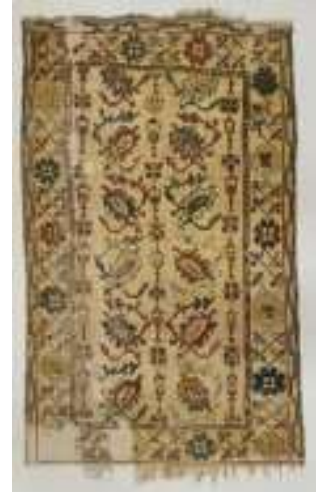

Resim 12. St. Margaret Kilisesi'ndeki halı (Ionescu, 2007: 111)

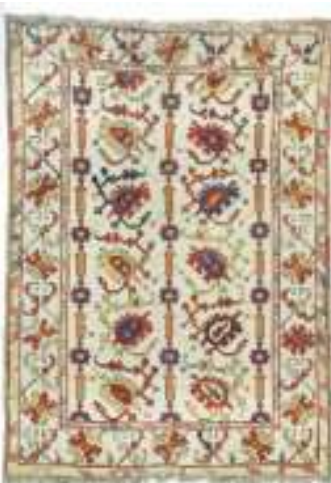

Resim 13. Budapeşte Uygulamalı Sanatlar Müzesi'ndeki halı (Pásztor, 2007: 111)

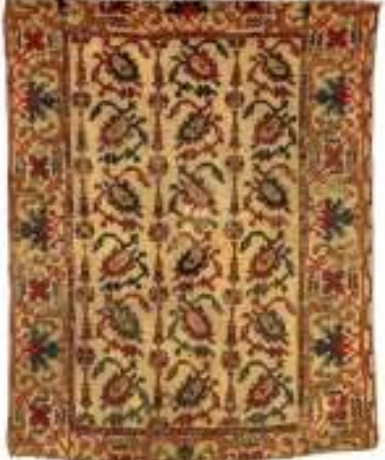

Resim 14. Keir Koleksiyonu'ndaki halı (John Taylor, URL7) 


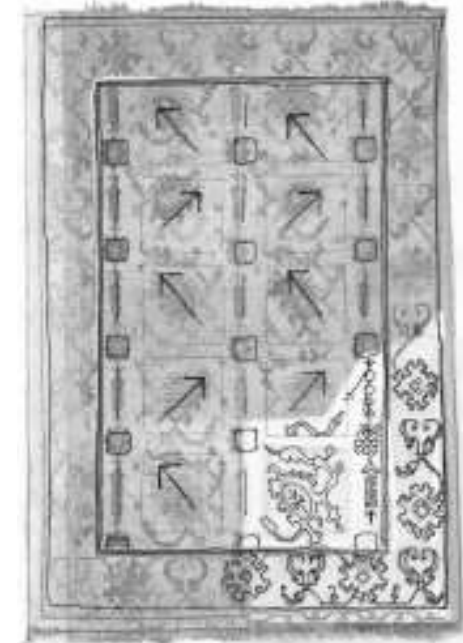

Çizim 5. Braşov Kara Kilise'deki halının kompozisyon sistematiğinin çizimi

(Çizim: Servet Senem Uğurlu, 2021)

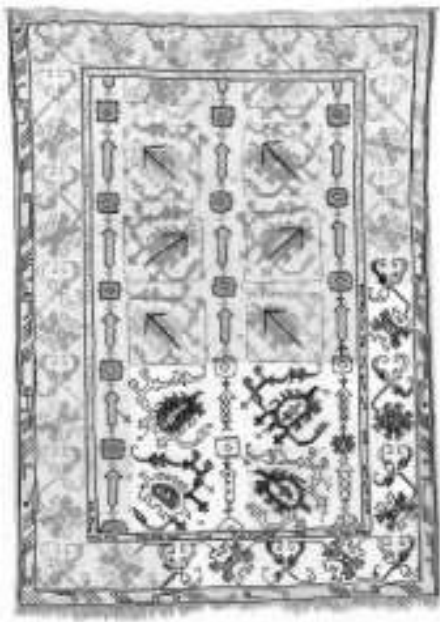

Çizim 7. Budapeşte Uygulamalı Sanatlar Müzesi'ndeki halının kompozisyon sistematiğinin çizimi (Çizim: Servet Senem Uğurlu, 2021)

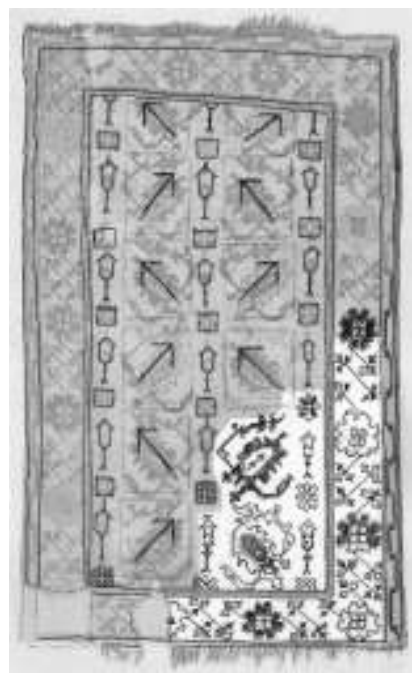

Çizim 6. Mediaş St. Margaret Kilisesi'ndeki halının kompozisyon sistematiğinin çizimi (Çizim: Servet Senem Uğurlu, 2021)

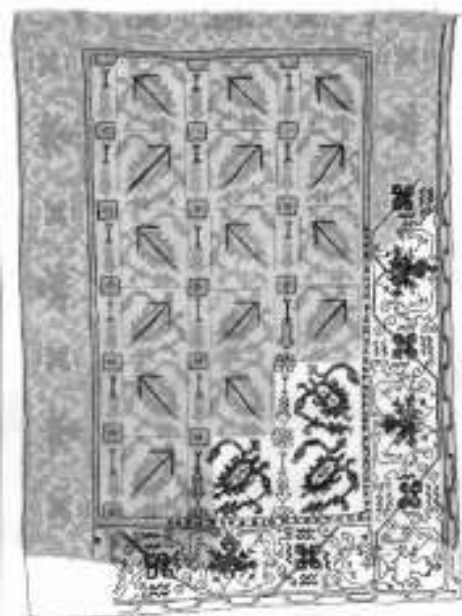

Çizim 8. Londra Keir Koleksiyonu'ndaki halının kompozisyon sistematiğinin çizimi (Çizim: Servet Senem Uğurlu, 2021)

Akrep motifi, kare alan birimi içerisinde geliştirilmiş, halı ortasındaki alanda sütun oluşturan motifler arasına tam ve şaşırtmacalı raportlar halinde yerleştirilmiştir. Motiflerin oluşturulmasında ise düz, kırık ve diyagonal çizgiler kullanılmıştır. 


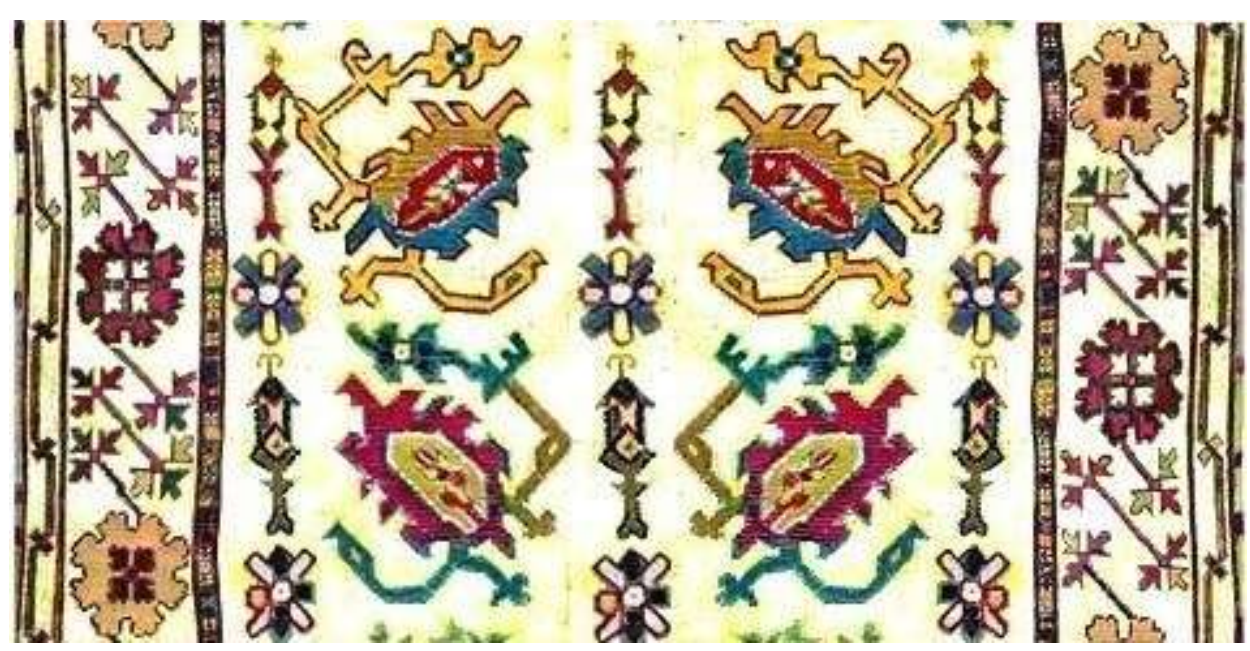

Çizim 9. Mediaş St. Margaret Kilisesi'ndeki beyaz zeminli akrep motifli Selendi halısının resimsel belgeleme çalışması (Çizim: Servet Senem Uğurlu, 2021)

Halıların desen kompozisyonları incelendiğinde, bu motif gruplarının orta alana sütunlar halinde yerleştirildiği görülür. Buna benzer kompozisyon sistematiği klasik dönem Osmanlı saray kumaşları ile kilimlerinde görülmektedir.

\section{Değerlendirme ve Sonuç}

Transilvanya bölgesinde Sakson ve Macar Protestan cemaatinin kilise ve müze depolarında 15. yüzyıl ikinci yarısından 18. yüzyılın sonuna kadar tarihlenen, bütün ya da parça halinde korunan yaklaşık olarak üçyüzseksen adet Anadolu halısı bulunduğu bilinmektedir (Ionescu, 2005: 41). Ayrica bu bölgeye, 13. yüzyılda Kolonizatör Türk dervişlerinden olan Sarı Saltuk ile gelen Yörük ve Türkmenler yerleşmişlerdir.

1526'da Mohaç Savaşı sonrasında yapılan ticaret, Transilvanya bölgesinde halı ticaretinin artmasına neden olmuştur. Birçok Avrupa ülkesinden gelen halı tüccarları, genelllikle İstanbul'da satılan Batı Anadolu halılarını özellikle Tuna Nehri doğrultusunda Transilvanya'ya götürmüşlerdir (Ionescu, 2005: 30). Bu rota, Orta Avrupa için en uygun ve maliyeti az ulaşım seçeneklerinden biri olmuştur. Transilvanya bölgesine halı ticareti, 18. yüzyıl sonuna kadar sürmüştür. Transilvanya'daki bu halılar, 19. yüzyılın ikinci yarısında yabancı halı tüccarlarının dikkatini çekmiştir. Tüccarların ucuza alıp pahalıya satma düşüncesi ile Kuzey Avrupa ülkelerinde "Halı Avı Dönemi" adı verilen bir süreç başlamıştır. Yirmibeş yıl gibi kısa süre içerisinde bu bölgedeki yüzlerce halı el değiştirmiş, çalınmış ya da yok pahasına satılmıştır.

Transilvanya bölgesinde yaşayan Saksonlar ellerindeki Anadolu halılarını bir kültür hazinesi olarak korumuşlar ve bağlı bulundukları kiliselere halılarını bağışlamışlardır. Romanya'daki Sakson ailelerin halılarını kiliseye bağışta bulunmaları ve kiliselerdeki halıların bakımlarına yardımcı olmaları sayesinde, Transilvanya'da çok sayıda halı günümüze ulaşabilmiştir. Bu bölgede bulunan Türk halı tipleri incelendiğinde; taşıması kolay ve namazlık büyüklüğünde olduğu görülmektedir. 20. yüzyılda Transilvanya kiliselerindeki Batı Anadolu halılarına ilgi giderek arttığ bilinmektedir.

Romanya'da tekstil firması olan bir ailenin bireyi Emil Schmutzler (1889-1952), kırsal kesimde yaptırdığı iki malikanesine, yöredeki kırsal kesimde yaşayan Sakson ailelerinden satın aldığ1 15-20 adet halıdan oluşan bir koleksiyon oluşturmuştur. 1933 yılında "Altorientalische Teppiche in Siebenbürgen" isimli kitabını Leipzig’te yayınlamıştır. Kitabı dönemin son teknolojisi ile renkli olarak basılmış ve Transilvanya halıları hakkında ilk kitap olması nedeniyle kendisine 
prestij sağlamıştır. 1944 yılında 2. Dünya Savaşı sırasında bombalanan evindeki koleksiyonundan ancak sekiz adet halı kurtarılmıştır (Ionescu, 2005: 209-210).

1930-1960 y1lları arasında Romanyalı usta halı tamircisi ve halı üreticisi Theodor Tuduc, atölyesinde Transilvanya kiliselerindeki halıların kopyalarını dokutturmuştur. Müze, koleksiyoner ve müzayede evlerindeki halı uzmanları bile Tuduc'un halılarının sahte olduklarını fark edememişlerdir (Ionescu, 2005: 212-215). Yüzyılın halı sahtekarı Tuduc'un sahte halıları, günümüzde dünyadaki bir çok müze ve koleksiyonda bulunmaktadır. Bu sahtekarlık, Anadolu halılarının sanatsal değerinin önemli bir kanıtı olmuştur.

Akrep motifli Selendi halıları olarak isimlendirilen halılardan günümüze sadece dört örnek ulaşmıştır. Bazı araştırmacı ve uzmanlar akrep motifini bazen yengeç bazen de bitkisel yaprak ve kırık dal olarak tanımlayarak açıklamışlardır. Hatta iki hayvanın mücadelesi olduğunu da iddia etmişlerdir. Bu iddialar devam edecektir. Çünkü geleneksel dokumalarda ikonografik motifler, göründüğünden farklı anlamlar taşıdığı için çeşitli yorumlara açıtır. Akrep motifli Selendi halılarındaki temel motifi hakkında farklı isimlendirme ve yorumlar şu şekildedir: Türk halıları hakkında geniş bilgi sahibi olan ve Türkiye'de İstanbul Üniversitesi'nde bir süre akademisyen olarak çalışmış Kurt Erdmann'ın 1965 tarihli kitabının 150. görselinde sahte bir Tuduc halısı, yanlışlıkla 1700 tarihli Uşak halısı olarak belirtilmiştir (Erdmann, 1965: 54). 1986 yılında Marino Dall'oglio bu motifleri yengece benzetir (Dall'Oglio, 1986: 191-192). 1986 yılında Ferenc Batári, bu motifi, yengeç olarak isimlendirmesi yanı sıra hatayi ve yaprak motiflerinin birleşiminden oluştuğunu ve muhtemelen kuş motifinden yararlanılarak geliştirildiğini yazmıştır (Batári, 1986: 201). 2007 yılında Michael Franses bu halılara akrepli ya da yengeçli olarak isimlendirme yapmış ve birbiriyle mücadele eden iki hayvana benzetmiştir (Franses, 2007: 69). 2007 yılında Emese Pásztor ise akrep, akrep palmetleri olarak iki farklı isimlendirme yapmıştır (Pásztor, 2007: 110).

Osmanlı Uşak Halıları içerisindeki beyaz zeminli halı grubunun Manisa ili Selendi ilçesinde dokunmuş olduğu Osmanlı kayıtlarından bilinmektedir. Bu halılar günümüze kadar Çintemani, üç benek, kuşlu/kargalı olarak belirtilmektedir (Aslanapa, 1987: 120,121, 123; 2005: 187, 194, 195). Ancak 17. yüzy1la tarihlenen, beyaz zeminli Selendi halılarıyla ilişkilendirilen, Transilvanya'da bulunan özel bir grup; Anadolu halılarını araştıran uzman ve araştırmacıların dikkati çekmiştir.

Sonuç olarak; bu araştırmada Türk Halıcılığında Türkiye'de neredeyse hiç bahsedilmemiş ve halı gruplarında sınıflandırmaya girmemiş beyaz zeminli akrep motifli Selendi halıları incelenmiştir. Bu halıların motif ve desen kompozisyonları çıkarılmış ve tasarımsal özellikleri açıklanmıştır. Özel olarak araştırılan beyaz zeminli akrep motifli Selendi halı grubunun, Türkiye'de Türk Halı literatürüne girmesi için çalışılmıştır.

\section{Kaynakça}

Akpınarlı, H. F. \& Begiç, N. \& Kuzay Demir, G. (2020). Çözgüden düğüme düğg̈mden motife Bergama halıları, Nobel Akademik Yayıncılık Eğitim Danışmanlık Tic. Ltd. Şti.

Arısan, K. \& Arısan Günay, D. (1995). Abdülaziz bey - Osmanlı adet, merasim ve tabirleri 2, Tarih Vakfi Yurt Yayınları.

Aslanapa, O. (1987). Türk halı sanatının bin yılı, Eren Yayıncılık ve Kitapçılık Ltd. Şti.

Aslanapa, O. (2005). Türk halı sanatının bin yılı, İnkılap Kitabevi Sanayi ve Ticaret A.Ş.

Ateş, S. (2014). Selendi kazası (dikey boyutta bir yerel tarih çalışması), [Yayımlanmamış yüksek lisans tezi]. Uşak Üniversitesi Sosyal Bilimler Enstitüsü. 
Balpinar, B. \& Hirsch, U. (1982). Flatchweaves of The Vakıflar Museum Istanbul / flachgewebe des Vakiflar-Museums Istanbul, Verlag Uta Hülsey.

Batári, F. (1986). White ground Anatolian carpets in the Budapest Museum of Applied Arts, Orientalental Carpet Textile Studies II Carpets of the Mediterranean Countries 1400-1600, 195-203.

Boz, L. (2013). Transilvanya bölgesi, Lutherci Mediaş Azize Margareth Kilisesindeki Anadolu halıları, [Yayımlanmamış yüksek lisans tezi]. Hacettepe Üniversitesi Sosyal Bilimler Enstitüsü.

Boz, L. (2014). Romanya'nın Transilvanya bölgesi Protestan kiliselerine halı bağışlama geleneği, Vakıflar dergisi, 42, 81-87.

Boz, L. (2015). Anatolische teppiche in der Margarethenkirche in Mediaş, Transilvanien / Anatolian carpets in The Saint Margaret's Church in Mediaş, Transylvania die entstehungsgeschichte einer masterarbeit im fach kunstgeschichte, a short story of a master's thesis in art history, Carpet collector teppiche und textilien für sammler, 4/2015, 80-87.

Dall'Oglio, M. (1986). White ground Anatolian carpet, Oriental carpet textile studies II carpets of the Mediterranean countries 1400-1600, 189-194.

Erbek, M, (2002). Çatalhöyük'ten günümüze Anadolu motifleri, Kültür Bakanlığı Yayınları.

Erdmann, K. (tarihsiz). Der Türkische teppich des 15. jahrhunderts / 15. asır Türk halısı, Çev.: Haldun Taner, İstanbul Üniversitesi Edebiyat Fakültesi.

Erdmann, K. (1963). Der Anatolische knüpfteppiche, Verlag Ernst Wasmuth Tübingen.

Erdmann, K. (1966). Siebenhundert jahre orient-teppich, Bussesche Verlagshandlung GmBH.

Ersoy, N. (2000). Semboller ve yorumlart, Kendisi.

Franses, M. (2007). “Transilvanya kiliselerindeki Osmanlı halıları”, Tanrı'ya adanmış halılar Transilvanya kiliselerinde Anadolu halıları 1500-1750, Sabanc1 Üniversitesi Yayınları, 51101.

Gezgin, D. (2007). Hayvan mitosları, Sel Yayıncılık.

Grimal, P. (1997). Mitoloji sözlüğü, (Çev.: Sevgi Tamgüç), Sosyal Yayınlar.

Güller, K. (1996a). Transilvanya halıları, Öneri, 1(4), 225-228.

Güller, K. (1996b). Transilvanya halıları, [Yayımlanmamış yüksek lisans tezi]. Marmara Üniversitesi Sosyal Bilimler Enstitüsü.

Ionescu, S. (2004). Transylvanian tale, Hall carpet, textile and Islamic art 137/2004, s.52-57.

Ionescu, S. (2005). Antique Ottoman rugs in Transylvania, Romaian Institute of Cultural.

Ionescu, S. \& Kertesz, A. (2007). Osmanlı halıları ve Transilvanya, Tanrı'ya adanmış halılar Transilvanya kiliselerinde Anadolu halıları 1500-1750, Sabancı Üniversitesi Yayınları, 3137.

Ionescu, S. (2010). Stefano Ionescu on Tuduc fakes, View from the Fringe, 18(2), 1-2.

Ionescu, S. (2012). Transylvanian rugs the collection of St. Margaret's Church in Mediash, International carpet \& textile review, 50, 7-19.

Ionescu, S. (2017). Anatolian rugs in Transylvanian churches, Alive Ihib's magazine of Anatolian rugs and kilims, 2017 January, 18-25. 
Ionescu, S. (2019). Transylvanian rugs, a highly successful Anatolian group / Anadolu'dan başarılı bir grup: "Transilvanya" halıları, 09 Ekim 2019 tarihli konferans, Romanya Kültür Enstitüsü “Dimitrie Cantemir" İtalyan Kültür Merkezi, İstanbul.

Iten-Maritz, J. (1991). Enzyklopädie des Orientteppiche, Verlag Busse + Seewald GmbH.

İleri, B. (2010). Ankara Vaklf Eserleri Müzesi'nde bulunan Uşak halılarının incelenmesi, [Yayımlanmamış yüksek lisans tezi]. Dokuz Eylül Üniversitesi Güzel Sanatlar Enstitüsü.

Kahraman, S. A. (2013). Evliya Çelebi- günümüz Türkçesiyle Evliyâ Çelebi seyahatnâmesi, Cilt 2, 7. Kitap, Yapı Kredi Yayınları.

Pásztor, E. (2007). Budapeşte Uygulamalı Sanatlar Müzesi koleksiyonundan Osmanlı-Türk halıları-Ferenc Batári anısina, Budapeşte Uygulamalı Sanatlar Müzesi Yayınları.

Reinhard G. H. (1972). Ullstein teppichbuch eine teppichkunde für kaufer und sammler, Verlag Ullstein GMBH.

Tezcan, H. (2011). Topkapı Müzesi koleksiyonundan tılsımlı gömlekler, Timaş Yayınları.

Uğurlu, A. (1987). Orta çağ Anadolu dokuma sanat1, İlgi, 48, 2-7.

Uğurlu, A. (2008). Panayırlar. Standard, 548, 43-45.

Uğurlu, S. S. (2020). Çanakkale-Ayvacık namazlık halıları. Turkish Studies, 15(7), 3123-3149. https://dx.doi.org/10.7827/TurkishStudies.43896

Wild, B. (2007). Transilvanya: iki dünya arasındaki rengarenk ülke, Tanrı'ya adanmış halılar Transilvanya kiliselerinde Anadolu halıları 1500-1750, Sabanc1 Üniversitesi Yayınları, 1523.

Yetkin, Ş. (1991). Türk halı sanatı, Türkiye İş Bankası Yayınları.

İnternet Kaynakları

URL1: https://www.wikiwand.com/de/Joseph_Lanzedelly_der_\%C3\%84ltere

(Erişim tarihi 22.05.2021)

URL2: https://www.britishmuseum.org/collection/object/P_1894-0612-75

(Erişim tarihi: 19.02.2021)

URL3:https://fr.wikipedia.org/wiki/Fichier:Lanzedelli_-

T\%C3\%A2rg \%C3\%AEn Transilvania 2.jpg (Erişim tarihi 22.05.2021)

URL4:https://en.m.wikipedia.org/wiki/File:Lanzedelli_-

T\%C3\%A2rg \%C3\%AEn Transilvania 4.jpg (Erişim tarihi 22.05.2021)

URL5:https://upload.wikimedia.org/wikipedia/commons/4/41/Lanzedelli_-

T\%C3\%A2rg \%C3\%AEn Transilvania 3.jpg (Erişim tarihi 22.05.2021)

URL6: https://selendihaber.blogspot.com/p/selendinin-nufusu.html (Erişim tarihi 19.05.2021)

URL7: https://www.rugtracker.com/2016/11/ (Erişim tarihi: 23.04.2021)

Kaynak Kişiler

KK1: Stefano Ionescu, sözlü görüşme (09.10.2019) 